Article

\title{
Hydropower Development and Fishways: A Need for Connectivity in Rivers of the Upper Paraná Basin
}

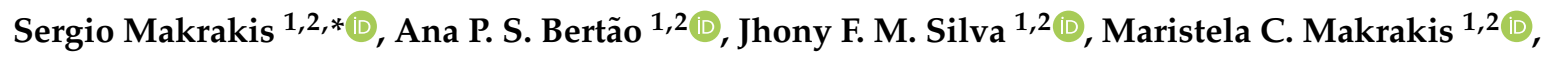 \\ Fco. Javier Sanz-Ronda ${ }^{3}\left(\mathbb{C}\right.$ and Leandro F. Celestino ${ }^{1,2, *(1)}$ \\ 1 Grupo de Pesquisa em Tecnologia em Ecohidráulica e Conservação de Recursos Pesqueiros e \\ Hídricos-GETECH, Universidade Estadual do Oeste do Paraná/ Rua da Faculdade, 645, Jd. Santa Maria, \\ Toledo, PR 85903-000, Brazil \\ 2 Programa de Pós-graduação em Recursos Pesqueiros e Engenharia de Pesca/ Rua da Faculdade, 645 Jd. \\ Santa Maria, Toledo, PR 85903-000, Brazil \\ 3 GEA-ecohidraulica.org, Universidad de Valladolid, E.T.S.II.AA. de Palencia, Avda. Madrid, 44, \\ 34004 Palencia, Spain \\ * Correspondence: sergio.makrakis@unioeste.br (S.M.); le_celestino@hotmail.com (L.F.C.)
}

Received: 31 May 2019; Accepted: 3 July 2019; Published: 9 July 2019

\begin{abstract}
South American rivers have become intensely affected by the construction of hydroelectric dams that block the river's connectivity for migratory fish species. In order to mitigate the problems caused by dams and to reestablish connections between habitats, fishways are implemented. Fishways are structures that aid fish in overcoming obstacles and help preserve migratory, reproductive, and feeding routes. This study performed an inventory of all hydropower plants-present and future-in the Upper Paraná River, with the objective of identifying fishways unknown to scientific literature, as well as the task of mapping them. By doing so, the current situation of structural connectivity via fishways in the Upper Paraná River Basin was described. Overall, 389 dams along 209 rivers were identified; of these, only $9 \%$ (35 dams) have fishways. In addition, an alarming explosion of future medium-sized hydropower plants was observed, with an expectation of an almost $500 \%$ increase in relation to those existing. This data reveals a trend of reduction of free-flowing river stretches, which are crucial habitats for Neotropical potamodromous species, and point to a deficiency in the structural connectivity of existing hydropower dams. Furthermore, if the implementations of these expected constructions are associated with limited connectivity as a result of the absence of fishways, the management of fisheries and their resources in the Upper Paraná River may become unsustainable.
\end{abstract}

Keywords: potamodromous fish; fish ladder; fisheries management; free-flowing rivers; Neotropical

\section{Introduction}

The great rivers of South America have been highly fragmented by hydroelectric dams in order to meet an ever-growing energy demand [1]. The construction of such dams is one of many anthropic actions which result in the greatest impact on hydrographic basins [2]. Among such impacts is the regulation of the river flow, which alters nutrient dynamics [3], fragments the ecosystem, changes the morphology of water bodies [4], and promotes the longitudinal imbalance of the rivers [5], which greatly decreases biodiversity and leads to the loss of biological and genetic resources $[2,6,7]$. Furthermore, this interferes in the migration of diadromous and potamodromous fish by blocking the connectivity between feeding, reproduction, and development habitats [8].

Potamodromous fish, which migrate solely in inland waters, are severely impacted by the fragmentation of rivers as a result of dams [9]. The Upper Paraná River Basin is home to approximately 310 fish species [10], of which 15-20 are long-distance migratory species [11-13], which are popularly 
known as 'piracema' fish [14], and can usually migrate hundreds of kilometers to reproduce [13,15]. Fish generally migrate longitudinally in an upstream spawning movement into the main river channel, followed by a downstream dispersion of eggs and larvae [11]. The intact longitudinal pathways are critical for survival, as well as the lateral migration into tributaries that are often very important for reproduction and can serve as nursery areas for larvae and young fishes [13,16,17]. Most of these species are very important for commercial and recreational fishing and represent a source of income and nourishment for local communities [18]. Several different management strategies, such as stocking programs and construction of fish passes [19], have been attempted in order to improve the sustainability of artisanal fishery and the social conditions of families who are dependent on this resource.

Fishways are constructed in order to reestablish connectivity between upstream and downstream areas [20-22]. By its basic definition, fishways are structures for conducting water by dissipating energy through baffles in order to provide a safe passage for migratory fish, without causing stress, delays, or injuries, and at a low expense of energy [21,23-25]. Fishways can be divided into (i) technical fishways, like fish ladders; (ii) nature-like structures, like bypass channels and rock ramps; and (iii) special-purpose structures, like elevators, fish locks, and eel passes [21,26,27]. Nature-like channels, aside from providing connectivity for fish species, also bear the highest resemblance to the natural habitat, due to the presence of invertebrates and macrophytes [24,28-31]. In contrast, fish ladders can be installed in higher dams and possess a shorter length as a result of the dissipation of water energy through baffles, consequently reducing the cost of installation [21,24,32]. Fish ladders have several designs which vary depending on the different types of baffles (also called weirs). As a result, they are known by different names, such as pool and weir, weir and orifice, vertical slot and Denil, and other mixed systems which present more than one design $[21,23,26]$.

Although several types of fish ladders have been implemented over the last three centuries [33], fishway science is still in its infancy, especially in South America [34]. The first fish passage constructed in Brazil was a fish ladder in the Atibaia River in 1911, at the Salto Grande Hydroelectric Dam in the São Paulo State [35]. This was followed by federal law n 794 of 1938, enforcing the use of fishways as follows: "Dams in rivers, streams, and creeks must have, as a mandatory complement, constructions that allow the conservation of fluvial fauna by either facilitating the passage of fish, or by installing fish farming". However, this federal law was subsequently revoked by law n 221 of 1967 as a result of its non-specificity and its enforcement of fishway construction even when not necessary. In the years that followed, some Brazilian states began to require constructions of fishways in waters within their boundaries, provided that the environmental agencies issue favorable technical advice. This was the case for both the states of São Paulo, with law n 9.798 of 1997, and Minas Gerais, with law $n^{\circ} 12.488$ of 1997.

In view of the mandatory nature of fishway implementation, combined with an absence of a specific technological understanding of tropical species, existing fishways in South America have followed a standard of size, hydraulic characteristics, and declivity based on fishways designed for salmonids and other potamodromous species of temperate climates [35,36]. The morphology, physiology, behavior, swimming capacity, and life history of Neotropical species, however, differ from those of temperate regions [14,37-40], for which these fish ladders were originally designed. Thus, the non-specificity of fishway projects undertaken in South America have furthered the installation of low-efficiency systems, which have prompted an overall distrust of their functionality [41-43]. To make matters worse, few hydroelectric enterprises perform adequate evaluations of attraction and efficiency, as well as the necessary monitoring [44]. Attraction is a metric that evaluates the amount of fish from a population that are able to find the fishway entrance, while efficiency is another metric that evaluates how many fish have passed through the fishway, regarding the amount which entered into the fishway-both metrics are generally expressed in percentages $[45,46]$. In addition, only a small percentage of the resulting fishway evaluation and monitoring reports are divulged to the scientific community [35]. This situation exacerbates the uncertainty regarding the fishways' performance, and 
in turn becomes an argument for the closure of already constructed fishways [47,48], as well as not implementing them at all in future projects. Nevertheless, ensuring structural connectivity, that is, the presence of physical structures that allow the movement of organisms [49], such as fish ladders, may be the first step in guaranteeing sustainability in fishery resources of regulated rivers [2].

Considering that the Upper Paraná River Basin is the most regulated in South America [1,11], along with the expectation of future hydropower plants, very little is actually known about the quantity, types, and dimensions of existing fishways. This lack of information is further inhibited by the scattering of existing data in different journals and environmental agencies—both state and federal—as well as the difficult access to projects and installations of hydropower plants and the spatial difficulty of visiting all of them in such a vast region. Therefore, the need for a public inventory is crucial for understanding the current and future situation of the Upper Paraná River Basin and to be able to guide the environmental management of the river and local fishery resources. This study quantified the hydropower dams-planned, under construction and in operation-in the Upper Paraná River Basin, identified and characterized the existing fishways, as well as summarized biologic and ecological aspects of the migratory species in the Upper Paraná River Basin.

\section{Materials and Methods}

The Paraná River basin has an extension of $2.8 \times 10^{6} \mathrm{~km}^{2}$ and covers roughly $80 \%$ of the Paraná-Paraguay River basin [11]. Also known as La Plata River basin, it includes areas of Brazil, Argentina, Bolivia, and Paraguay (Figure 1). The Paraná River is formed by the confluence of the Paranaíba and Grande rivers and possesses important tributaries such as Tietê, Sucuriú, Verde, Pardo, Aguapeí, Ivinhema, Amambaí, Iguatemi, Paranapanema, Ivaí, Piquiri, and Iguaçu rivers. This fluvial system is distributed through areas of Brazil, Paraguay, and Argentina. The main trajectory of the Paraná River is roughly $4600 \mathrm{~km}$ in length, and the annual sediment load is estimated to be over $1.5 \times 10^{8}$ tons [50]. The mainstem of the Upper Paraná River extends $750 \mathrm{~km}$ upstream of the Itaipu Dam (Brazil-Paraguay border) and northeasterly up to the confluence of the Grande and Paranaíba rivers [22], comprising Brazilian and Paraguayan territory. However, due to the lack of information regarding hydroelectric power plants and their respective fishways in Paraguay, this study limits itself to the dams located in the Upper Paraná River Basin within Brazilian territory, including the Iguaçu River and its tributaries. The Upper Paraná River in Brazil partly drains the states of Goiás, Minas Gerais, Mato Grosso do Sul, São Paulo, Paraná, and Santa Catarina.

\subsection{Data Collection}

\subsubsection{Spatial Distribution and Classification of Hydroelectric Dams}

The coordinates of hydroelectric dams in operation, planned and under construction, were obtained through the Georeferenced Information System of the Electric Sector (SIGEL-https://sigel. aneel.gov.br/portal/home/) of the Brazilian National Hydroelectric Agency (ANEEL), accessed in May of 2018. The data obtained was processed in the Shapefile format by the Geographical Information System (SIG) QGIS 2.18 [51], with the World Geographical System (WGS 84).

The hydropower dams were classified into three groups, according to the guidelines set by the ANEEL, based on the installed power (Megawatt-MW) and the area of the reservoir: (i) small-sized (Central Geradora Hidrelétrica-CGH), installed power rated at $\leq 3 \mathrm{MW}$, divided into microgenerators, with installed power rated at $>0.075$ and $\leq 3 \mathrm{MW}$ [52]; (ii) medium-sized (Pequena Central Hidrelétrica $-\mathrm{PCH}$ ) -installed power rated at $>3 \mathrm{MW}$ and $\leq 30 \mathrm{MW}$, including a reservoir with an area up to $13 \mathrm{~km}^{2}$ [53]; and (iii) large (Usina Hidrelétrica de Energia—UHE)—installed power rated at >30 MW [54]. 


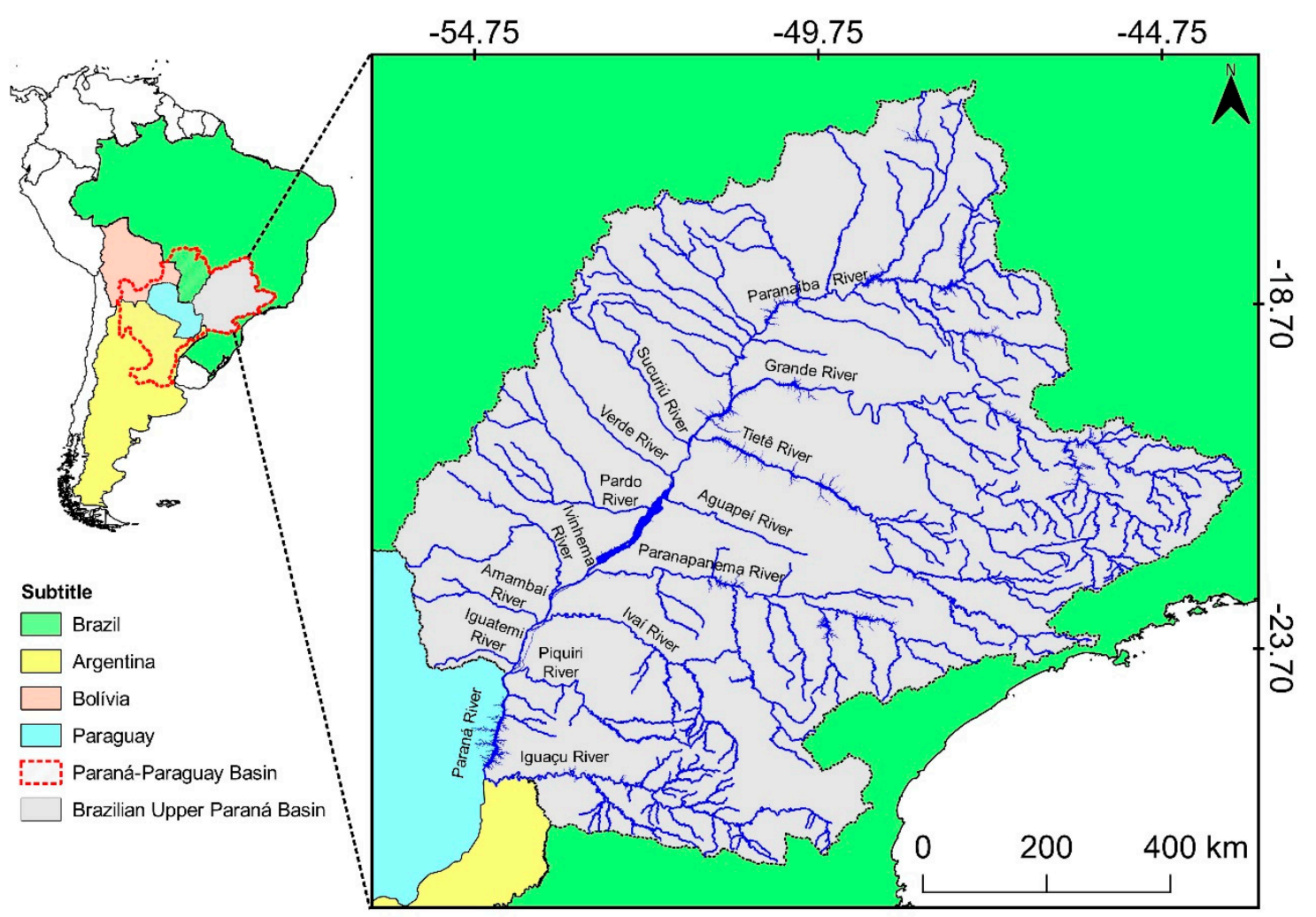

Figure 1. The Upper Paraná River Basin in Brazilian territory and its main tributaries.

\subsubsection{Fishway Survey}

The geographical coordinates of the hydropower plants in operation obtained through the ANEEL website were inserted into the Google EarthTM software and were utilized to visually inspect each hydroelectric enterprise to verify the existence of fishways [1]. The information regarding the types of fishways, design, construction date, and materials, were obtained through broad review of available literature, including scientific articles, books, and reports. The origin of the information regarding the fishways were classified into scientific sources (books and articles), reports (from environmental agencies, hydroelectric plants, universities, as well as doctorate thesis), and visual inspection (fishways which did not have any previous mention in the literature and were identified for the first time through Google EarthTM). With a basis in the available data, the fishways (type and design) were categorized according to Clay (1995), Larinier (2001), and Silva et al. (2018) [21,26,27].

\subsubsection{River Connectivity}

A risk map of river connectivity of the Upper Paraná River Basin was constructed. For this, the river stretches were quantified and classified in three categories: (i) blocked-river stretches fragmented by dams without fishways; (ii) connected-river stretches dammed but connected by fishways at dams; (iii) free-flowing river stretches-river stretches with natural flow.

It was considered hydropower plants in operation, however, only in this analysis the Baixo Iguaçu Dam (large-sized), the last one of a cascade of dams along the Iguaçu River, was included, which started the operation in March 2019.

\subsubsection{Bioecological Aspects and Conservation Status of Migratory Species}

A review of the literature was conducted to summarize some biological and ecological aspects of migratory species occurring in the Upper Paraná River Basin: status of conservation [55-57]; maximum standard length $[12,58,59]$, feeding $[11,60,61]$, spawning season $[12,58,61-63]$, habitat $[12,61]$, and migratory movements [13]. 


\subsection{Data Analysis}

The proportions of the types of hydropower plants in operation (CGH, PCH and UHE), as well as the proportions of fishway types were tested by the chi-square test for equal proportion, while the proportions of fishways by type of hydropower plant were tested by the likelihood test and Fisher's exact test. All the analyses were performed by the PROC FREQ procedure of the SAS University Edition 9.4 (Cary, NC, USA), with a significance level of $5 \%$.

\section{Results}

\subsection{Hydropower Development}

Overall, ANEEL's database provided information regarding 974 hydropower plants, of which $59.2 \%(\mathrm{n}=577)$ are planned for construction, $0.8 \%(\mathrm{n}=8)$ are under construction, and $39.9 \%(389$ plants) are in operation (Table 1).

The proportion of dams in operation was different between the types of hydroelectric power plants (CGH, PCH, and UHE) (test for equal proportions: $\mathrm{x}^{2}=59.850, \mathrm{df}=2, p<0.001$ ). The proportion of CGH in operation was $51.7 \%(n=201)$ and was greater to the proportion of PCH and UHE, which represented $26.2 \%(n=102)$ and $22.1 \%(n=86)$, respectively (Table 1$)$. The proportions of PCH and UHE did not differ significantly (test for equal proportions: $\mathrm{x}^{2}=1.361, \mathrm{df}=1, p=0.243$ ). The spatial distribution of $\mathrm{CGH}, \mathrm{PCH}$ and UHE in operation are illustrated in Figure 2.

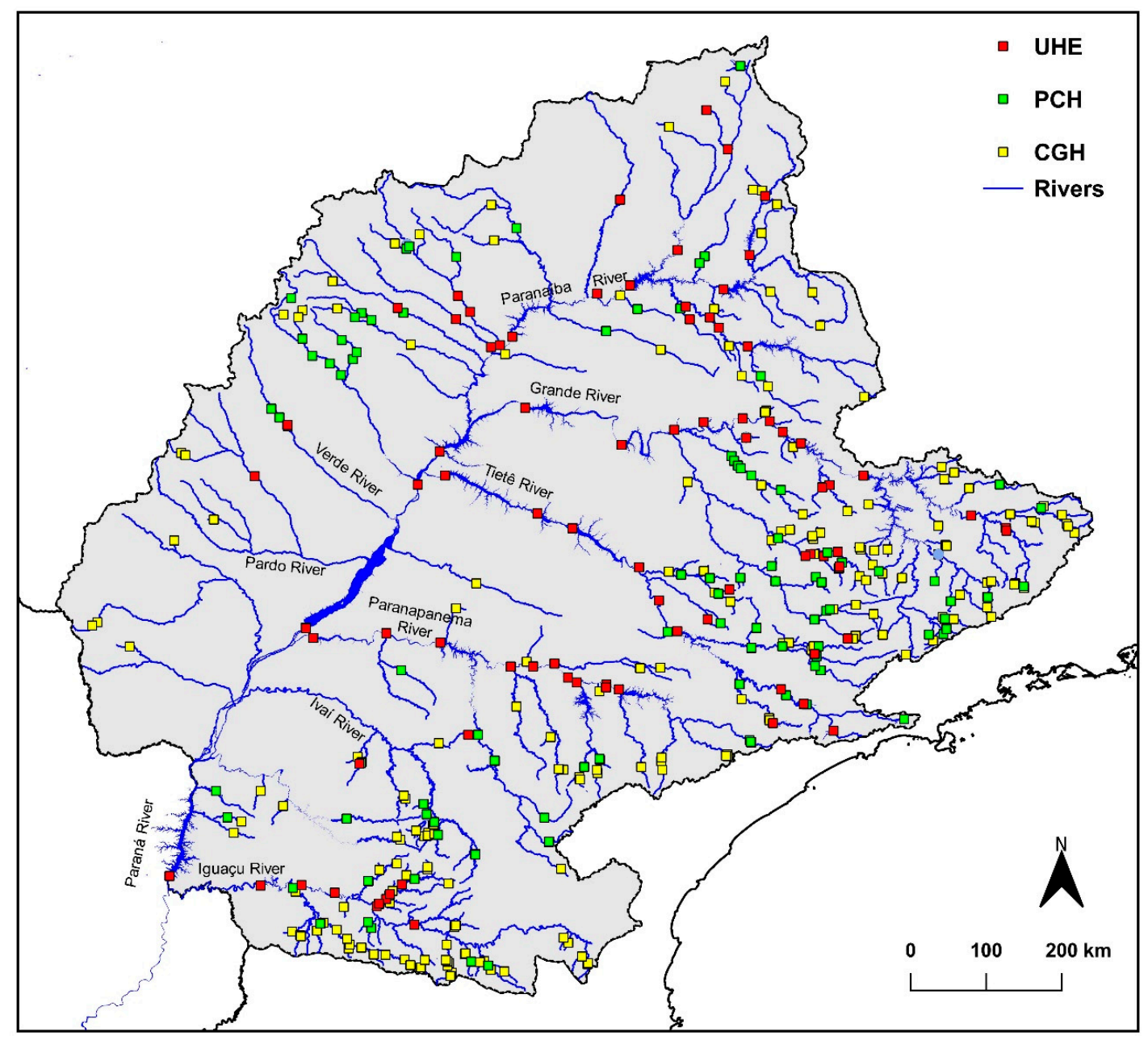

Figure 2. Distribution map of hydropower dams in the main rivers from Upper Paraná River Basin, by type of enterprise: $\mathrm{UHE}=$ large, $\mathrm{PCH}=$ medium, and CGH = small-sized hydropower plants. 
Table 1. Number of hydropower plants planned, under construction, and in operation according to ANEEL.

\begin{tabular}{ccccc}
\hline Hydropower Plant Classification & Planned & Under Construction & In Operation & Total \\
\hline Large-sized: UHE & 61 & 2 & 86 & $\mathbf{1 4 9}$ \\
Medium-sized: PCH & 516 & 6 & 102 & $\mathbf{6 2 3}$ \\
Small-sized: CGH & - & - & 201 & $\mathbf{2 0 1}$ \\
\hline Total & 577 & $\mathbf{8}$ & $\mathbf{3 8 9}$ & $\mathbf{9 7 4}$ \\
\hline
\end{tabular}

In relation to future hydropower plants, the proportion of planned PCHs was of $89.4 \%(n=516)$ and was greater to the proportion of planned UHEs, which represented only $10.6 \%(n=61)$. Therefore, the number of future PCHs $(n=516)$ represented a five-fold $(505 \%)$ increase in relation to PCHs in operation, whereas the number of future UHEs represented an increase of $71 \%$ (Table 1 ).

\subsection{Fishway by Hydropower}

A total number of 37 fishways were identified and distributed between 35 dams. The Engenheiro Sérgio Motta Hydropower Plant (UHE) has two fishways-a fish ladder and an elevator, and the São Joaquim ( $\mathrm{PCH}$ ) has two fish ladders (Table 2). The percentage of fishways differed between the CGH, $\mathrm{PCH}$, and UHE (likelihood ratio: $\mathrm{x}^{2}=32.074, \mathrm{df}=2, p<0.001$ ). The proportion of CGHs with fishways $(1.5 \% ; \mathrm{n}=3)$ was significantly lower in relation to PCHs (Fisher's exact test: $p<0.001)$, as well as UHEs (Fisher's exact test: $p<0.001)$. Nevertheless, the proportion of hydropower plants with fishways did not differ significantly between PCHs $(20.6 \%, \mathrm{n}=21)$ and UHEs $(12.8 \% ; \mathrm{n}=11)$ (Fisher's exact test: $p=0.176)$.

\subsection{Fishway Information Profile}

There was no significant difference in proportion of the type of information regarding fishways, that is, fishways without information (fishway found by visual inspection), with scientific information, and with reports (test for equal proportions: $\mathrm{x}^{2}=1.523, \mathrm{df}=2 p=0.469$ ). Overall, of the 37 fishways encountered, $35.1 \%(n=13)$ did not possess any type of available information and were only identified for the first time through satellite imaging (Figure 3A; Table 2). Alternatively, $40.5 \%$ of the fishways $(n=15)$ displayed scientific information (articles or books) in regard to evaluation of attraction, efficiency, or continuous monitoring. Finally, $24.3 \%$ of the fishways $(n=9)$ had information available through reports, which can best be described as grey literature (Figure 3A). Of the fish passages with available scientific information, the fish ladder at Engenheiro Sérgio Motta hydropower dam (known as Porto Primavera, São Paulo State) stood out as the most studied, having been the subject of seven published scientific articles.

\subsection{Fishway Types}

The proportion of fishway types varied in relation to fish ladders, elevators, and lateral system. Fish ladders were predominant, representing $91.9 \%(n=34)$ of all constructed fishways, while elevators corresponded to $5.4 \%(n=2)$, and lateral system only accounted for $2.7 \%(n=1)$ (Figure 3B).

Of the 34 fish ladders, no information about design was found for $44.1 \%(n=15)$, whereas for $55.9 \%(n=19)$, some information was available. Of these $55.9 \%$, with respect to design, $26.5 \%(n=9)$ were pool and weir, $23.5 \%(n=8)$ were weir and orifice, $2.9 \%(n=1)$ were vertical slot, and $2.9 \%(n=1)$ were of a mixed design (Figure 3C). Photos of the different types and designs of these fishways can be seen in Figure A1. 

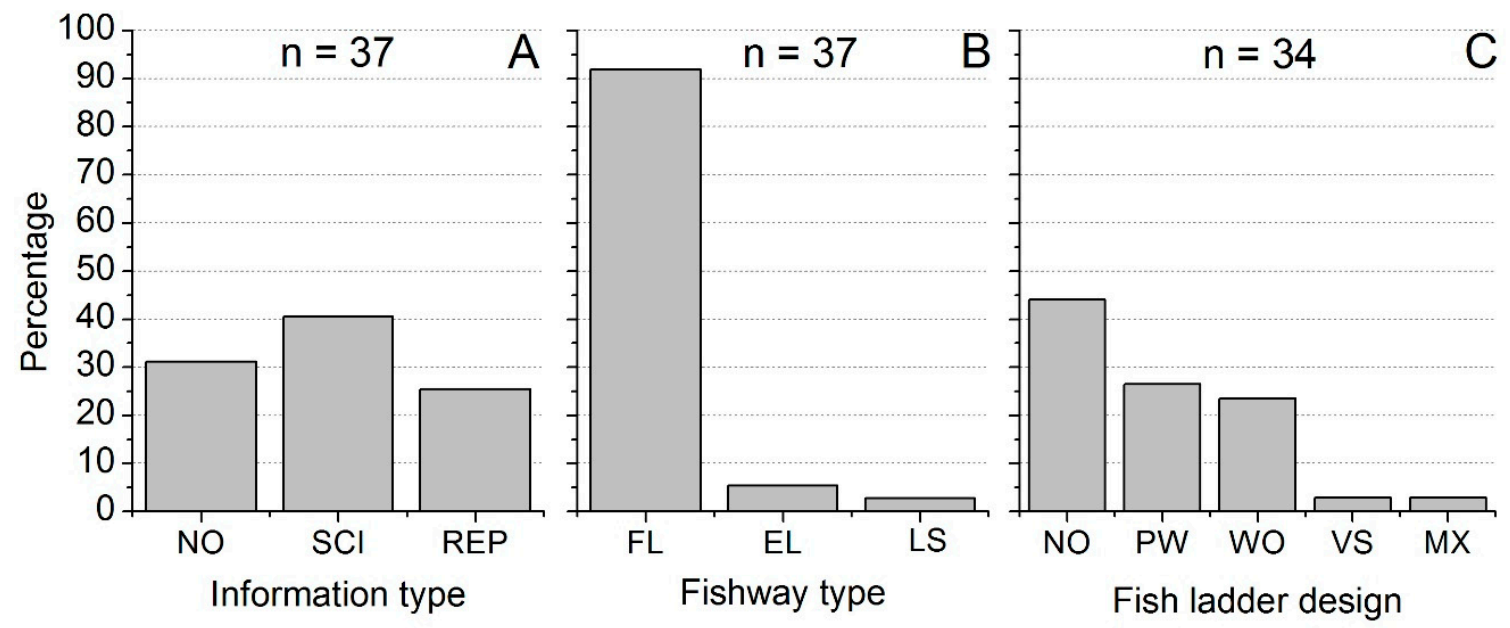

Figure 3. Origin of the information regarding encountered fishways: $\mathrm{NO}=$ no previous information (first records of the transposition system), SCI = fishway with available scientific information (articles or books), and REP = grey literature information (reports, theses, webpages) (A). Percentage of the types of fishways found in the Upper Paraná River basin: FL = fish ladder, EL = elevator, and LS = lateral system (B). Designs of encountered fish ladders: $\mathrm{NO}=$ no information regarding baffle types, $\mathrm{PW}=$ pool and weir, $\mathrm{WO}=$ weir and orifice, VS = vertical slot, and MX = mixed designs (more than one design) (C).

\subsection{History of Fishways in the Upper Paraná River Basin}

The fishways in the Upper Paraná River Basin that possess information regarding their construction date $(n=19)$ were built between 1911 and 2015 (a 104-year interval), resulting in an age mean of 47.1 years. In general, $41.1 \%$ of these $(n=8)$ were constructed within the last 18 years (Figure $4 \mathrm{~A})$, preceded by $21 \%(n=4)$ from 1940 to $1959,15.8 \%(n=3)$ from 1900 to $1919,10.5 \%(n=2)$ from 1980 to 1999 , $5.3 \%(n=1)$ from 1920 to 1939 , and $5.3 \%(n=1)$ from 1960 to 1979 . In regard to fish ladder designs, pool and weir was the most widely utilized until the 1950s. From the 1950s onward, what are thought to be more efficient fish ladder designs gained popularity, predominantly weir and orifice designs (Figure 4B). In addition, the unique fish ladder with vertical slot design was built in the 1980-99 period. Alternatively, mixed designs such as the lateral system, Canal da Piracema, as well as elevators, were constructed exclusively from 2000-2018 (Figure 4B).

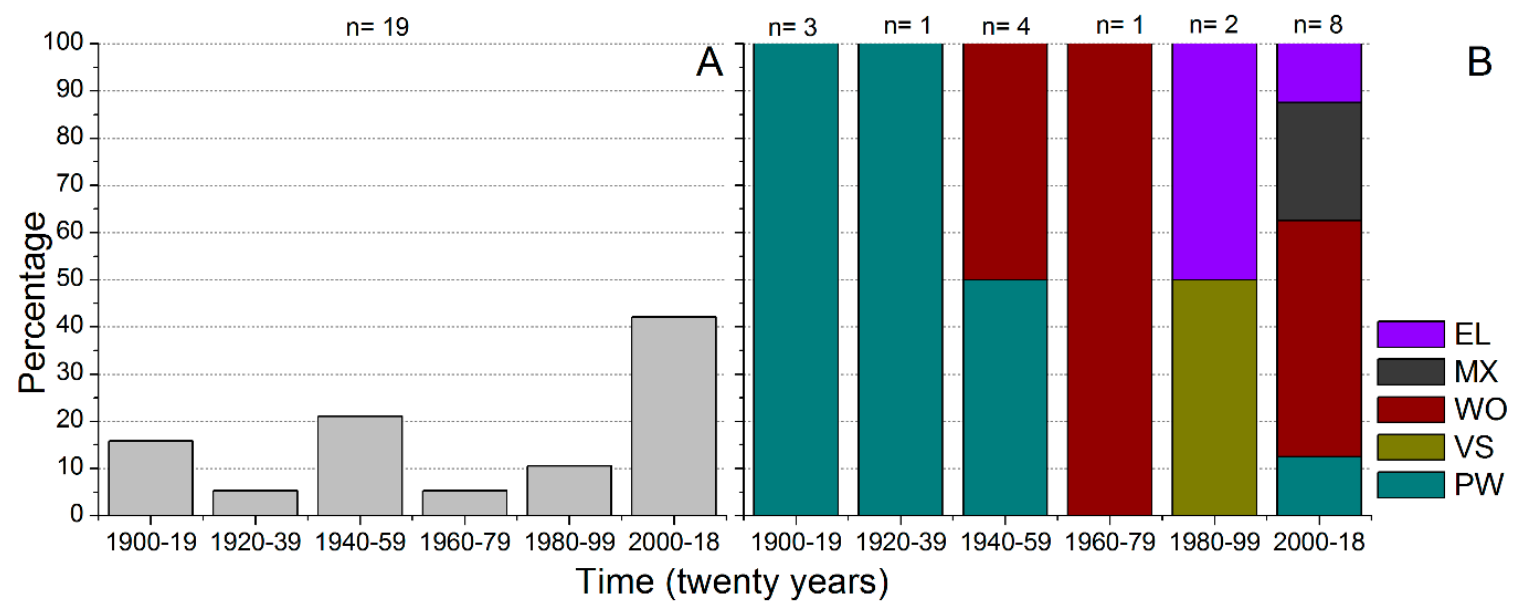

Figure 4. Percentage of fishways constructed per 20-year period in the Upper Paraná River Basin (A). Fishway type and fish ladder design constructed per 20-year period $(\mathbf{B})$. $\mathrm{PW}=$ pool and weir, $\mathrm{WO}=$ weir and orifice, VS = vertical slot, $\mathrm{EL}=$ elevator and $\mathrm{MX}=$ mixed system (includes fishways with more than one design). 
Table 2. List of hydropower plants with fishways and their characteristics. FL $=$ fish ladder, $\mathrm{EL}=$ elevator, $\mathrm{LS}=$ lateral system, $\mathrm{NO}=$ no information available, $-=$ not applicable, ${ }^{*}=$ disabled fishway, $\bullet=$ fishway with efficiency information. Dam ID represents the spatial positioning of the dam in Figure 5.

\begin{tabular}{|c|c|c|c|c|c|c|c|c|c|}
\hline $\mathbf{N}$ & Dam ID & Dam Name & Coordinates $\mathrm{X}, \mathrm{Y}$ & River & $\begin{array}{l}\text { Fishway } \\
\text { Type }\end{array}$ & Year & Fishway Design & $\begin{array}{c}\text { Baffle } \\
\text { Type/Material }\end{array}$ & References \\
\hline \multicolumn{10}{|c|}{ Large-Sized-UHE } \\
\hline 1 & 05 & Igarapava & $\begin{array}{l}-19.989255^{\circ} \\
-47.755567^{\circ}\end{array}$ & Grande & FL• & 1999 & Vertical Slot & -/Concrete & {$[64,65]$} \\
\hline 2 & 24 & Canoas I & $\begin{array}{l}-22.939658^{\circ} \\
-50.517983^{\circ}\end{array}$ & Paranapanema & $\mathrm{FL}^{*} \bullet$ & 2000 & Weir and Orifice & $\begin{array}{l}\text { Bottom orifice and } \\
\text { notch/Concrete }\end{array}$ & {$[48,62,66,67]$} \\
\hline 3 & 25 & Canoas II & $\begin{array}{l}-22.939505^{\circ} \\
-50.251990^{\circ}\end{array}$ & Paranapanema & $\mathrm{FL}^{*} \bullet$ & 2000 & Weir and Orifice & $\begin{array}{l}\text { Bottom orifice and } \\
\text { notch/Concrete }\end{array}$ & {$[48,62,66,67]$} \\
\hline 4 & 26 & Ourinhos & $\begin{array}{l}-23.070170^{\circ} \\
-49.838412^{\circ} \\
\end{array}$ & Paranapanema & $\mathrm{FL} \bullet$ & 2005 & Pool and Weir & -/Concrete & [68] \\
\hline 5 & 28 & Piraju I & $\begin{array}{l}-23.154237^{\circ} \\
-49.379971^{\circ}\end{array}$ & Paranapanema & FL & 1971 & Weir and Orifice & $\begin{array}{c}\text { Bottom } \\
\text { orifice/Concrete }\end{array}$ & {$[62,69-71]$} \\
\hline 6 & 29 & Piraju II & $\begin{array}{l}-23.187694^{\circ} \\
-49.384466^{\circ}\end{array}$ & Paranapanema & FL & NO & Weir and Orifice & $\begin{array}{c}\text { Bottom } \\
\text { orifice/Concrete }\end{array}$ & [69] \\
\hline 7 & 06 & São Domingos & $\begin{array}{l}-20.083344^{\circ} \\
-53.174786^{\circ}\end{array}$ & Verde & FL & 2015 & Weir and Orifice & $\begin{array}{l}\text { Bottom orifice and } \\
\text { notch/Metal }\end{array}$ & [72] \\
\hline 8 & 22 & $\begin{array}{c}\text { Engenheiro Sérgio } \\
\text { Motta (Porto } \\
\text { Primavera) }\end{array}$ & $\begin{array}{l}-22.483899^{\circ} \\
-52.957212^{\circ}\end{array}$ & Paraná & $\mathrm{FL} \bullet$ & 2001 & Weir and Orifice & $\begin{array}{l}\text { Bottom orifice and } \\
\text { notch/Concrete }\end{array}$ & $\begin{array}{c}{[22,34,38,39} \\
73-75]\end{array}$ \\
\hline 9 & 22 & $\begin{array}{c}\text { Engenheiro Sérgio } \\
\text { Motta (Porto } \\
\text { Primavera) }\end{array}$ & $\begin{array}{l}-22.483899^{\circ} \\
-52.957212^{\circ}\end{array}$ & Paraná & $\mathrm{EL} \bullet$ & 1999 & Pipe and Gravity & -/Metal & [76-79] \\
\hline 10 & 35 & Itaipu Binacional & $\begin{array}{l}-25.430486^{\circ} \\
-54.581765^{\circ}\end{array}$ & Paraná & LS• & 2002 & $\begin{array}{l}\text { Semi-natural } \\
\text { Vertical Slot } \\
\text { Pool and weir }\end{array}$ & $\begin{array}{c}\text {-/Concrete, rocks and } \\
\text { excavated }\end{array}$ & {$[41,80-82]$} \\
\hline 11 & 01 & Rochedo & $\begin{array}{l}-17.388624^{\circ} \\
-49.216373^{\circ}\end{array}$ & Meia Ponte & FL & NO & $\mathrm{NO}$ & $\mathrm{NO} / \mathrm{NO}$ & [83] \\
\hline 12 & 12 & Funil & $\begin{array}{l}-21.144011^{\circ} \\
-45.036538^{\circ}\end{array}$ & Grande & EL & 2004 & Flume channel & -/Metal & {$[44,84,85]$} \\
\hline
\end{tabular}


Table 2. Cont.

\begin{tabular}{|c|c|c|c|c|c|c|c|c|c|}
\hline $\mathbf{N}$ & Dam ID & Dam Name & Coordinates $\mathrm{X}, \mathrm{Y}$ & River & $\begin{array}{l}\text { Fishway } \\
\text { Type }\end{array}$ & Year & Fishway Design & $\begin{array}{c}\text { Baffle } \\
\text { Type/Material }\end{array}$ & References \\
\hline \multicolumn{10}{|c|}{ Medium-sized-PCH } \\
\hline 13 & 34 & Salto Mauá & $\begin{array}{l}-24.058585^{\circ} \\
-50.712232^{\circ}\end{array}$ & Tibagi & FL & 1943 & Pool and Weir & -/Concrete & {$[62,69,71,86]$} \\
\hline 14 & 04 & Salto Moraes & $\begin{array}{l}-18.950109^{\circ} \\
-49.382568^{\circ}\end{array}$ & Tijuco & $\mathrm{FL} \bullet$ & 1951 & Weir and Orifice & $\begin{array}{c}\text { Bottom } \\
\text { orifice/Concrete }\end{array}$ & {$[62,71,87]$} \\
\hline 15 & 14 & $\begin{array}{l}\text { João Baptista de } \\
\text { Lima Figueiredo }\end{array}$ & $\begin{array}{l}-21.584954^{\circ} \\
-46.746961^{\circ}\end{array}$ & Pardo & FL & $\mathrm{NO}$ & $\mathrm{NO}$ & $\mathrm{NO} / \mathrm{NO}$ & [83] \\
\hline 16 & 21 & Corumbataí & $\begin{array}{l}-22.480472^{\circ} \\
-47.592333^{\circ}\end{array}$ & Corumbataí & FL & NO & Pool and Weir & $\mathrm{NO} /$ Concrete & [88] \\
\hline 17 & 07 & Retiro & $\begin{array}{l}-20.436132^{\circ} \\
-47.889945^{\circ}\end{array}$ & Sapucaí & FL & NO & $\mathrm{NO}$ & $\mathrm{NO} / \mathrm{NO}$ & [83] \\
\hline 18 & 08 & Anhanguera & $\begin{array}{l}-20.493856^{\circ} \\
-47.858010^{\circ}\end{array}$ & Sapucaí & FL & NO & $\mathrm{NO}$ & $\mathrm{NO} / \mathrm{NO}$ & [83] \\
\hline 19 & 09 & Palmeiras & $\begin{array}{l}-20.550638^{\circ} \\
-47.813264^{\circ}\end{array}$ & Sapucaí & FL & NO & $\mathrm{NO}$ & $\mathrm{NO} / \mathrm{NO}$ & [83] \\
\hline 20 & 10 & São Joaquim & $\begin{array}{l}-20.581831^{\circ} \\
-47.780019^{\circ}\end{array}$ & Sapucaí & FL & NO & $\mathrm{NO}$ & $\mathrm{NO} / \mathrm{NO}$ & [89] \\
\hline 21 & 10 & São Joaquim & $\begin{array}{l}-20.581831^{\circ} \\
-47.780019^{\circ}\end{array}$ & Sapucaí & FL & 1911 & Pool and Weir & -/Concrete & {$[69,89]$} \\
\hline 22 & 11 & Dourados & $\begin{array}{l}-20.666837^{\circ} \\
-47.654310^{\circ}\end{array}$ & Sapucaí & FL & 1926 & Pool and Weir & -/Concrete & [69] \\
\hline 23 & 13 & Itaipava & $\begin{array}{l}-21.413491^{\circ} \\
-47.334915^{\circ}\end{array}$ & Pardo & FL & 1911 & Pool and Weir & -/Concrete & {$[69,71]$} \\
\hline 24 & 27 & San Juan & $\begin{array}{l}-23.149462^{\circ} \\
-47.793913^{\circ}\end{array}$ & Sorocaba & FL & NO & $\mathrm{NO}$ & $\mathrm{NO} / \mathrm{NO}$ & [83] \\
\hline 25 & 23 & Salto Grande & $\begin{array}{l}-22.933744^{\circ} \\
-46.896052^{\circ}\end{array}$ & Atibaia & FL & 1911 & Pool and Weir & -/Concrete & {$[35,83,90]$} \\
\hline
\end{tabular}


Table 2. Cont

\begin{tabular}{|c|c|c|c|c|c|c|c|c|c|}
\hline $\mathbf{N}$ & Dam ID & Dam Name & Coordinates $\mathrm{X}, \mathrm{Y}$ & River & $\begin{array}{c}\text { Fishway } \\
\text { Type }\end{array}$ & Year & Fishway Design & $\begin{array}{c}\text { Baffle } \\
\text { Type/Material }\end{array}$ & References \\
\hline 26 & 18 & Cachoeira de Emas & $\begin{array}{l}-21.926500^{\circ} \\
-47.366357^{\circ}\end{array}$ & Mogi-Guaçu & $\mathrm{FL} \bullet$ & $\begin{array}{l}1922 \\
1943\end{array}$ & Pool and Weir & -/Concrete & {$[71,91-93]$} \\
\hline 27 & 20 & Mogi-Guaçu & $\begin{array}{l}-22.379299^{\circ} \\
-46.900892^{\circ}\end{array}$ & Mogi-Guaçu & FL & $\mathrm{NO}$ & Pool and Weir & -/Concrete & {$[83,94]$} \\
\hline 28 & 19 & São José & $\begin{array}{l}-21.938628^{\circ} \\
-46.816218^{\circ}\end{array}$ & Jaguari Mirim & FL & $\mathrm{NO}$ & $\mathrm{NO}$ & $\mathrm{NO}$ & [83] \\
\hline 29 & 33 & $\begin{array}{c}\text { Cachoeira Poço } \\
\text { Preto II }\end{array}$ & $\begin{array}{l}-24.047850^{\circ} \\
-49.457784^{\circ}\end{array}$ & Itararé & FL & $\mathrm{NO}$ & $\mathrm{NO}$ & $\mathrm{NO}$ & [83] \\
\hline 30 & 32 & $\begin{array}{c}\text { Cachoeira Poço } \\
\text { Preto I }\end{array}$ & $\begin{array}{l}-24.036877^{\circ} \\
-49.462776^{\circ}\end{array}$ & Itararé & FL & $\mathrm{NO}$ & $\mathrm{NO}$ & $\mathrm{NO}$ & [83] \\
\hline 31 & 03 & Jataí & $\begin{array}{l}-17.943613^{\circ} \\
-51.726355^{\circ}\end{array}$ & Claro & FL & $\mathrm{NO}$ & $\mathrm{NO}$ & $\mathrm{NO}$ & [83] \\
\hline 32 & 02 & Ypê & $\begin{array}{l}-17.725705^{\circ} \\
-50.451810^{\circ}\end{array}$ & Verdão & FL & $\mathrm{NO}$ & $\mathrm{NO}$ & $\mathrm{NO}$ & [83] \\
\hline 33 & 15 & Gavião-Peixoto & $\begin{array}{l}-21.847628^{\circ} \\
-48.489485^{\circ}\end{array}$ & Jacaré-Guaçu & FL & $\begin{array}{l}1913 \\
1987 \\
1995 \\
2007\end{array}$ & $\begin{array}{l}\text { Mixed system: } \\
\text { Pool and weir and } \\
\text { excavated rock }\end{array}$ & -/Concrete and rocks & {$[43,95]$} \\
\hline 34 & 16 & Capão Preto & $\begin{array}{l}-21.895113^{\circ} \\
-47.814506^{\circ}\end{array}$ & Quilombo & FL & $\mathrm{NO}$ & $\mathrm{NO}$ & $\mathrm{NO} / \mathrm{NO}$ & {$[83,96]$} \\
\hline \multicolumn{10}{|c|}{ Small-sized-CGH } \\
\hline 35 & 17 & Quatiara & $\begin{array}{l}-21.951352^{\circ} \\
-50.929426^{\circ}\end{array}$ & Do Peixe & FL & 1949 & Weir and Orifice & Notch/concrete & [69] \\
\hline 36 & 30 & Santa Adélia & $\begin{array}{l}-23.327529^{\circ} \\
-47.768980^{\circ}\end{array}$ & Sorocaba & FL & $\mathrm{NO}$ & $\mathrm{NO}$ & $\mathrm{NO} / \mathrm{NO}$ & [83] \\
\hline 37 & 31 & Do Túnel & $\begin{array}{l}-23.414886^{\circ} \\
-50.452437^{\circ}\end{array}$ & Laranjinha & FL & $\mathrm{NO}$ & $\mathrm{NO}$ & $\mathrm{NO} / \mathrm{NO}$ & [83] \\
\hline
\end{tabular}


From all 37 fishways found, $24.3 \%(n=9)$ have some kind of information regarding efficiency, while only $5.4 \%(n=2)$ were rebuilt or structurally modified to improve their efficiency. The first to undergo modifications/reconstruction was the Cachoeira das Emas fish ladder in the Mogi-Guaçu River, São Paulo State, built in 1922 and rebuilt in 1943 (Table 2). Additionally, the Gavião-Peixoto fish ladder in the Jacaré-Guaçu River was built in 1913 and was rebuilt in 1987, 1995, and 2007 (Table 2).

\subsection{Structural Connectivity by Fishways}

Regarding all the hydropower plants currently in operation in the Upper Paraná River Basin $(n=389)$, only $9 \%(n=35)$ have some type of fishway to provide structural connectivity (Figure 5). Furthermore, at least two fish ladders are inactive, both are fish ladders in the Paranapanema River at the Canoas I and II dams (Table 2).

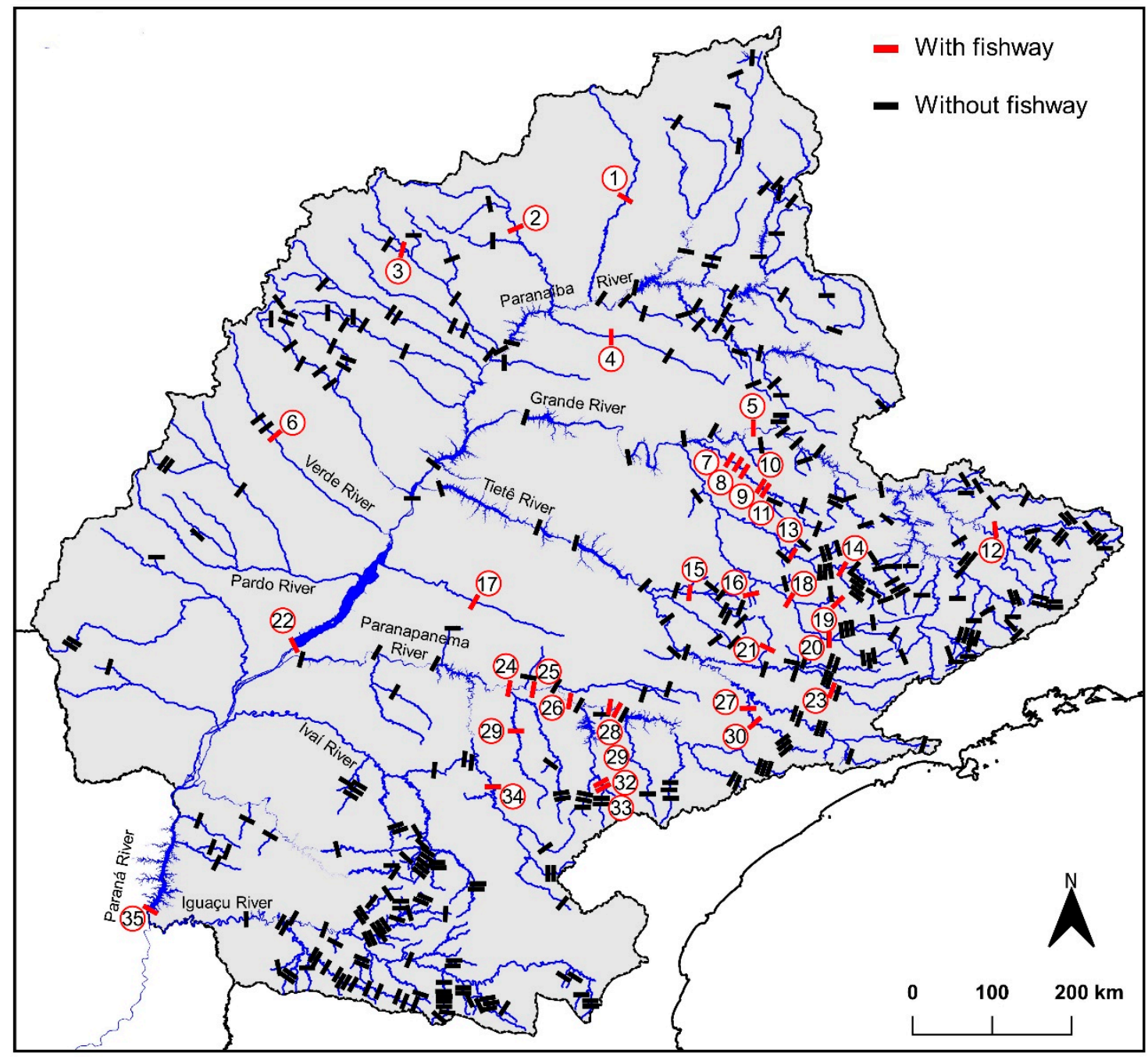

Figure 5. Distribution of hydropower dams in the main rivers of the Paraná River Basin. Black dashes indicate dams without fishways, and red dashes indicate dams with fishways. Numbers within the red circles represent the dam ID with fishways and can be found in Table 2.

The Upper Paraná River Basin is composed of a fluvial network that extends through 154,608 km, where 209 rivers $(32,490.4 \mathrm{~km})$ of this network have at least one hydropower dam, which corresponds to 0.0119 dam $\mathrm{km}^{-1}$. However, only $10 \%(\mathrm{n}=21)$ of these rivers have some type of fishway to provide structural connectivity (Figure 6). The main water courses of the Upper Paraná River Basin are composed of a 31,454 km river network, where only $9 \%(2788 \mathrm{~km})$ are connected by fishways, $48 \%$ $(15,187 \mathrm{~km})$ are blocked, and $43 \%(13,598 \mathrm{~km})$ are free-flowing (Figure 6). 


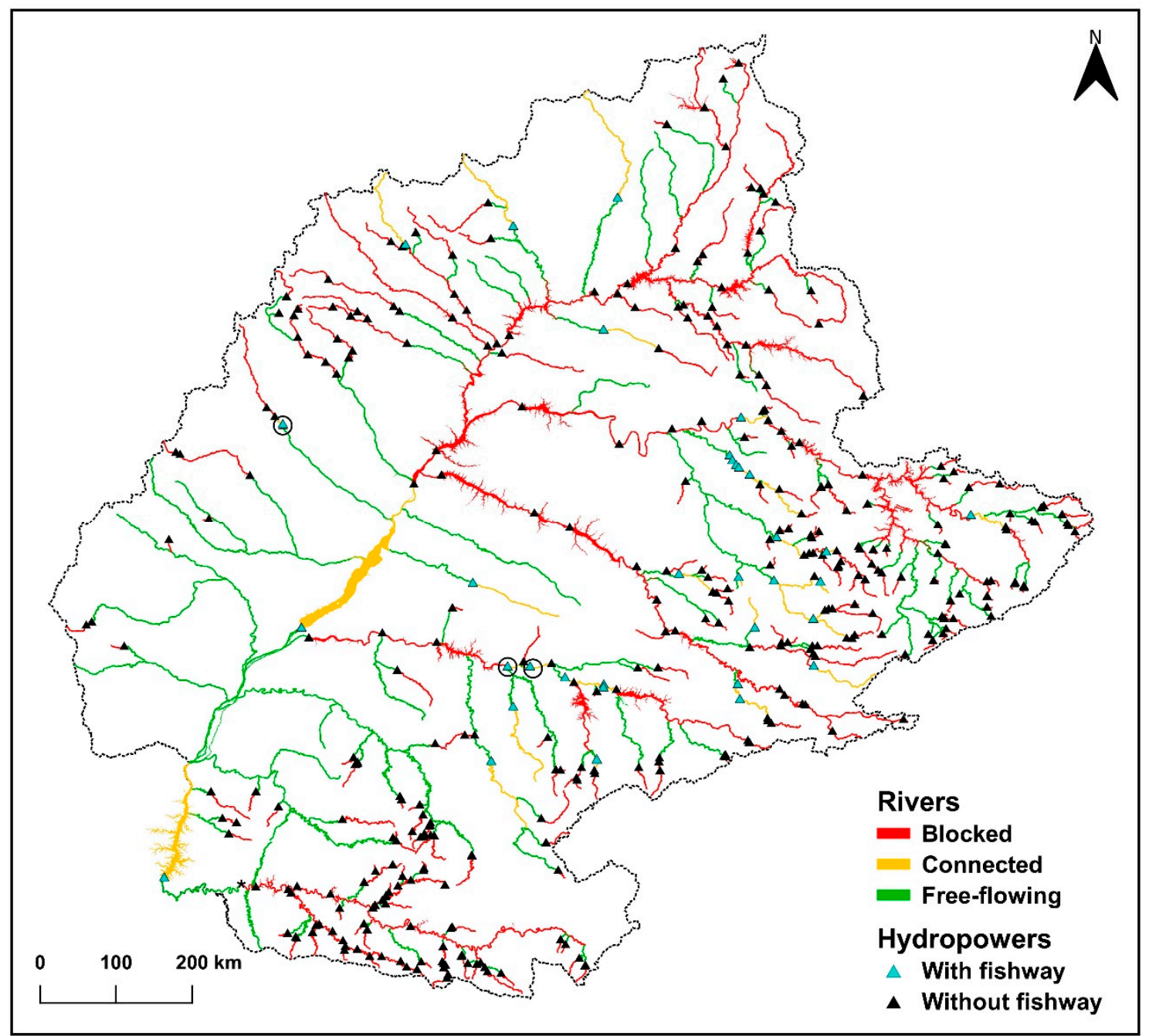

Figure 6. Risk map of river connectivity in the Upper Paraná Basin illustrating hydropower dams and the stretches of rivers: blocked, connected by fishways, and free-flowing. The circles indicate disabled fishways, and the asterisk indicates Baixo Iguaçu Dam.

The Paranapanema and Sapucaí rivers present the highest number of dams with fishways $(n=5)$, followed by the Grande, Itararé, Paraná, Pardo, Sorocaba, and Mogi-Guaçu rivers ( $\mathrm{n}=2$ each river), while the other rivers have only one dam with a transposition system (Table 3 ).

Within a geopolitical distribution, $71.4 \%$ of dams with fishways $(n=25)$ reside within the state of São Paulo, followed by the states of Minas Gerais, Goiás, and Paraná, with $8.6 \%(n=3)$ each, and the state of Mato Grosso do Sul with 2.9\% ( $\mathrm{n}=1)$ (Table 3). 
Table 3. Rivers of the Upper Paraná Basin with fishways and their respective length, slope, quantities of dams per river, dams with fishways, and the percentage of dams that provide connectivity via fishway. Dam location corresponds to the state in which the dam is located. ${ }^{*}$ Indicates that the river flows on the border of a neighboring state, but the dam with the fishway follows the legislation of the state marked by the asterisk. \# Indicates a fishway in each state.

\begin{tabular}{|c|c|c|c|c|c|c|c|}
\hline $\mathbf{N}$ & River & $\begin{array}{c}\text { River } \\
\text { Length } \\
(\mathbf{k m})\end{array}$ & $\begin{array}{c}\text { River } \\
\text { Slope } \\
(\%)\end{array}$ & $\begin{array}{l}\text { Number } \\
\text { of Dams } \\
\text { per River }\end{array}$ & $\begin{array}{l}\text { Number of } \\
\text { Dams per } \\
\text { River with } \\
\text { Fishway }\end{array}$ & $\begin{array}{c}\% \text { of Dams } \\
\text { with Fishway } \\
\text { per River }\end{array}$ & Dam Location (State) \\
\hline 1 & Atibaia & 181.5 & 0.23 & 2 & 1 & 50.0 & São Paulo \\
\hline 2 & Claro & 353.8 & 0.14 & 4 & 1 & 25.0 & Goiás \\
\hline 3 & Corumbataí & 84.7 & 0.29 & 1 & 1 & 100.0 & São Paulo \\
\hline 6 & Itararé & 197.8 & 0.21 & 2 & 2 & 100.0 & São Paulo \\
\hline 7 & Jacaré-Guaçu & 171.7 & 0.21 & 2 & 1 & 50.0 & São Paulo \\
\hline 8 & Jaguari-mirim & 98.3 & 0.21 & 2 & 1 & 50.0 & São Paulo \\
\hline 9 & Laranjinha & 257.8 & 0.26 & 1 & 1 & 100.0 & Paraná \\
\hline 10 & Meia Ponte & 434.9 & 0.16 & 1 & 1 & 100.0 & Goiás \\
\hline 15 & Quilombo & 35.7 & 0.56 & 1 & 1 & 100.0 & São Paulo \\
\hline 16 & Sapucaí & 305.8 & 0.17 & 5 & 5 & 100.0 & São Paulo \\
\hline 17 & Sorocaba & 204.1 & 0.19 & 5 & 2 & 40.0 & São Paulo \\
\hline 18 & Tibagi & 336.8 & 0.11 & 2 & 1 & 50.0 & Paraná \\
\hline 19 & Tijuco & 274.8 & 0.15 & 2 & 1 & 50.0 & Minas Gerais \\
\hline 20 & Verdão & 384.3 & 0.15 & 1 & 1 & 100.0 & Goiás \\
\hline \multirow[t]{2}{*}{21} & Verde & 386.3 & 0.07 & 3 & 1 & 33.3 & Mato Grosso do Sul \\
\hline & Total & 7365.1 & - & 75 & 35 & 46.7 & - \\
\hline
\end{tabular}

\subsection{Bioecological Aspects and Conservation Status of Migratory Species}

Eighteen migratory fish species are listed in Table 4, which occur in the Upper Paraná River Basin. Some species are rare in this region, such as Salminus hilarii, Steindachneridion scriptum and Zungaro jahu. Regarding the status of conservation, six species are threatened, among them one near threatened, NT, (Pseudoplatystoma corruscans); two vulnerable, VU, (Salminus brasiliensis, Rhinelepis aspera); and three endangered species, EN, (Brycon orbignyanus, S. scriptum and Z. jahu). However, B. orbignyanus is also classified as critically endangered, CR, in the State of São Paulo, Brazil. The migratory fish are medium and large-sized species (characiformes, catfish and armored catfish) and exhibit varied feeding, with short reproductive periods (ranging from two to four months) between October and March. Most species are restricted to stretches of free-flowing rivers (FFRS) of dams, in the mainstem and/or tributaries, while some species also inhabit reservoir-dammed areas (Prochilodus lineatus, Pimelodus maculatus, Pinirampus pirinampu, Pterodoras granulosus, and Rhaphiodon vulpinus). Migratory species move longitudinally in the mainstem river, upstream and/or downstream, as well as most species perform lateral movements in dam-free tributaries.

Particularly in the Lower Iguaçu River, upstream of the Iguaçu Falls, there is an endemic and endangered species, and possibly migratory, Steindachneridion melanodermatum, similarly to S. scriptum. This species is restricted to a river stretch of $190 \mathrm{~km}$, dam-free, and its knowledge is still limited. 
Table 4. Migratory fish species in the Upper Paraná River Basin. CR = critically endangered, EN = endangered, VU = vulnerable, NT = near threatened, maximum standard length $(\mathrm{SL}), \mathrm{FFRS}=$ free-flowing river stretches of dam, RES $=$ reservoir, $\mathrm{LON}=$ longitudinal, $\mathrm{UP}=\mathrm{upstream}, \mathrm{DO}=\mathrm{downstream}, \mathrm{LAT}=$ lateral, $*=$ rare species, ${ }^{1}=$ MMA (2014) [56]; ${ }^{2}=$ São Paulo (2018) [55], ${ }^{3}=$ Abilhoa \& Duboc (2004) [57].

\begin{tabular}{|c|c|c|c|c|c|c|c|}
\hline Family and Species & Common Name & Status of Conservation & SL (cm) & Feeding & Spawning Season & Habitat & Migratory Movements \\
\hline \multicolumn{8}{|l|}{ CHARACIFORMES } \\
\hline \multicolumn{8}{|l|}{ Anostomidae } \\
\hline Megaleporinus obtusidens & Piapara & & 51.7 & Omnivorous & Dec-Jan & FFRS & LON-UP \\
\hline Megaleporinus piavussu & Piapara & & 40.0 & Omnivorous & Nov-Jan & FFRS & \\
\hline Megaleporinus macrocephalus & Piavuçu & & 50.0 & Omnivorous & - & FFRS & \\
\hline \multicolumn{8}{|l|}{ Bryconidae } \\
\hline Brycon orbignyanus & Piracanjuba & $\mathrm{EN}^{1}, \mathrm{CR}^{2}$ & 62.5 & Insectivorous & Oct-Jan & FFRS & LONG-UP \\
\hline Salminus brasiliensis & Dourado & $\mathrm{VU}^{3}$ & 85.9 & Piscivorous & Oct-Jan & FFRS & LON-UPDO, LAT \\
\hline Salminus hilarii* & Tabarana & & 34.0 & Piscivorous & Nov-Jan & FFRS & \\
\hline \multicolumn{8}{|l|}{ Cynodontidae } \\
\hline Rhaphiodon vulpinus & Dourado-cachorro & & 78.0 & Piscivorous & Out-Jan & FFRS, RES & - \\
\hline \multicolumn{8}{|l|}{ Prochilodontidae } \\
\hline Prochilodus lineatus & Curimba & & 54.2 & Iliophagous & Oct-Jan & FFRS, RES & LON-UPDO, LAT \\
\hline \multicolumn{8}{|l|}{ Serrasalmidae } \\
\hline Piaractus mesopotamicus & Pacu & & 52.6 & Omnivorous & Oct-Jan & FFRS & LON-UP, LAT \\
\hline \multicolumn{8}{|l|}{ SILURIFORMES } \\
\hline \multicolumn{8}{|l|}{ Doradidae } \\
\hline Pterodoras granulosus & Armado & & 63.5 & Omnivorous & Jan-Mar & FFRS, RES & LON-UPDO, LAT \\
\hline Rhinelepis aspera & Cascudo-preto & $\mathrm{VU}^{3}$ & 49.0 & Iliophagous & Oct-Jan & FFRS & \\
\hline \multicolumn{8}{|l|}{ Pimelodidae } \\
\hline Hemisorubim platyrhynchos & Jurupoca & & 51.4 & Piscivorous & Dec-Jan & FFRS & LON-UP \\
\hline Pimelodus maculatus & Mandi amarelo & & 36.0 & Omnivorous & Nov-Jan & FFRS, RES & LON-UPDO, LAT \\
\hline Pinirampus pirinampu & Barbado & & 68.0 & Piscivorous & Dec-Jan & FFRS, RES & LON-UPDO, LAT \\
\hline Pseudoplatystoma corruscans & Pintado & $\mathrm{NT}^{3}$ & 140.0 & Piscivorous & Nov-Feb & FFRS & LON-UP, LAT \\
\hline Sorubim lima & Jurupensem & & 60.5 & Piscivorous & Nov-Dec & FFRS & \\
\hline Steindachneridion scriptum* & Surubim & $\mathrm{EN}^{1}$ & 64.0 & Piscivorous & Dec-Jan & FFRS & \\
\hline Zungaro jahu* & Jaú & $\mathrm{EN}^{2}$ & 83.0 & Piscivorous & Dec-Feb & FFRS & \\
\hline
\end{tabular}




\section{Discussion}

The fragmentation of rivers caused by dams is one of the leading factors of population decline in fish species [4]. Despite the negative effects on migratory and resident fish species, there are still ongoing plans to develop new hydropower dams, mainly in regions of high hydropower potential that have yet been unexploited, much like the basins of the Congo, Mekong, and Amazon rivers [97,98]. Therefore, the future of these free-flowing stretches of the Upper Paraná River Basin may be compromised, due to an expected 505\% increase in medium-sized dams (PCHs). It is possible that this elevated number of medium-sized dams is the result of an exhaustion of the great hydraulic potentials caused by the construction of large-sized hydropower plants (UHEs) within the last 50 years [1]. This scenario jeopardizes migratory fish to an even greater risk than they face with existing dams.

Overall, 389 hydropower dams were identified, and only 35 (9\%) of them have fishways in the Brazilian Upper Paraná Basin (some dams have more than one fishway, totaling 37 fishways overall). Although 37 fishways is a proportionally small number (9.5\%) in comparison to 389 dams, the number of fishways encountered in this study alone was greater than the 25 fishways listed in all South America according to the most recent fishway inventory performed by Lira et al. [44]. These authors, however, only utilized information derived from scientific articles. By contrast, the results encountered in this study were derived from the integration of different research methods, such as scientific literature, grey literature, and satellite imaging, which provided the description of 13 new fishways in the Upper Paraná River Basin.

The number of fishways in this study was much higher in the state of São Paulo than in the five other Brazilian states drained by the Upper Paraná River. This fact may be related to current state legislation which requires the construction of fishways, when the position of the state environmental agency is favorable [99]. The state with the second largest number of fishways was Minas Gerais, which also has legislation regarding fishway implementation [100], while the other states that are part of Upper Paraná Basin do not have specific legislation regarding fishways. Despite some Brazilian states possessing legislation that describes the implementation of fishways whenever pertinent $[99,100]$, there is no legislation that enforces the evaluation or monitoring of these structures. Once built, the evaluation and monitoring of the fishway depends entirely on requests from the environmental agencies and how it affects their granting of operating licenses for each hydropower plant. Otherwise, the necessary evaluation and monitoring will depend on the good faith of the developers. It is important to remember that the mere existence of a fishway will not guarantee that it will function as desired, especially when considering that the observed efficiency of existing structures hardly ever surpasses $30 \%$.

This reality certainly explains the absence of scientific literature regarding fishways in the region this study took place. For the most part, fishways with scientific information are a result of partnerships with the hydropower companies and universities which utilize these fishways as a subject of study [44]. This is the case of the fish ladder at Engenheiro Sérgio Motta Hydropower Plant (Porto Primavera, SP), which is the subject of the highest number of published scientific articles [34,38,39,73-75], followed by Itaipu Binacional—Canal da Piracema [41,80-82], Canoas I and II [48,66], but it is also the reality of other fishways in the Tocantins River, Amazon Basin [101-103]. Many fishways in South America that have been evaluated are deemed selective or inefficient $[41,80,104,105]$, and despite efficiency problems being commonplace, only two fishways have been modified or reconstructed in an aim to improve their efficiency, as were the cases of the Cachoeira das Emas [71,91] and the Gavião-Peixoto fish ladders $[43,95]$. 
During the data collection for this study, there was a predominance of fish ladders in relation to other types of fishways (elevators and lateral system). The small number of recorded elevators in this study could be a result of negative experiences with this fishway type in South American rivers. Evaluations conducted in some elevators showed low biomass transposition, high operational cost, and electromechanical problems [42,78,79]. Furthermore, the transposition of fish in this system is unidirectional (from downstream to upstream), not allowing the return of fish from upstream to downstream [106]. These factors may have contributed to the non-installation of this type of fishway in the other dams.

The lateral system found in this study, the Canal da Piracema, located at the Itaipu Dam, is more than $10 \mathrm{~km}$ long, and is considered the longest fishway in the world, comprising different designs such as semi-natural, vertical slot, and pool and weir $[80,82]$. Nature-like systems possess characteristics similar to those found in nature, facilitating the passage of fish, as they can offer habitats for aquatic organisms [31] and provide restored environments when compared to technical fishways [28]. Additionally, in some cases, nature-like systems and technical fishways can be favored over other structures such as elevators and fish locks, as they may allow for bidirectional connectivity [22,29]. A large part of fish ladders constructed in the Upper Paraná River until 1960 were of pool and weir design, and although they are encountered in a much higher frequency, they are considered to be fairly selective, as they favor jumper fish and limit the passage of fish which swim at the bottom [24,107]. Later, however, more adequate designs were implemented, such as weir and orifice and vertical slot, which permit the passages of benthic as well as pelagic fish species.

Fishways should obligatorily be implemented when: (i) there are native migratory species that require passage through the area where the axis of the dam is located; (ii) there is no impassable natural barrier that separates habitats prior to the construction of the dam (e.g., waterfalls); (iii) migratory species present a spatial distribution in both stretches that are to be fragmented by the dam, that is, where gene flow is present; and (iv) there are habitats favorable for spawning upstream from the axis of the future dam [108]. It is very likely that many of the 354 dams without fishways in the Upper Paraná River Basin would fit these four criteria proposed by Makrakis et al. [108], which would justify the implementation of fishways. Considering that the majority of hydropower dams do not permit a connection to the stretch of river blocked by the dam, it can be assumed that vast stretches have been highly fragmented, and consequently, gene flow in the Upper Paraná River has been compromised. Rivers which are prominently inhabited by migratory species are considerably fragmented, such as the Grande River, which hosts 12 dams, and only 2 of them (16.7\%) provide fishways; the Pardo River, with 2 dams (28.6\%); the Mogi-Guaçu River with 2 dams (33.2\%); and the Paranapanema, a large tributary which spans roughly $1,000 \mathrm{~km}$, with only 5 dams (45.5\%) (Table 3). The Paranapanema River is especially notable, as the Rosana Hydropower Plant, which does not offer a fishway, is $25 \mathrm{~km}$ from where it meets the Paraná River, thereby severely hindering connectivity with the mainstream. Studies have shown that populations of long-distance migratory species in this tributary have been reduced [109], and this fact may be associated with the lack of connectivity at Rosana Dam.

New dams are expected and they could drastically reduce the number of free-flowing stretches, which are important areas for the maintenance of potamodromous species [110]. In the Paraná River mainstem, the preservation of the free-flowing river stretches, the floodplain of Upper Paraná River, which extends about $230 \mathrm{~km}$ from the Guaíra municipality up to downstream of the Porto Primavera Dam, is essential for the maintenance of fish diversity (Figure 6). Regarding the main tributaries in the Upper Paraná River Basin, notably the Aguapeí, Ivinhema, Iguatemi, Ivaí and Piquiri and Capanema (a tributary of Iguaçu River) rivers are completely free-flowing rivers and must be preserved (Figure 6). Additionally, other rivers that are partially dammed and have long free-flowing stretches require special attention because they are important areas of spawning and nursery for migratory fish species, e.g., the Pardo, Verde and Lower Iguaçu rivers [17,110-112]. 
The role of fishways in connectivity for some long-distance migratory species in Neotropical rivers has been widely studied, and its efficacy has been proven, as was the case of the Porto Primavera fish ladder $[17,22,34,39,73,74,113]$. A long period of monitoring the Porto Primavera fish ladder has shown that the fish ladder can provide bidirectional connectivity for some fish species, such as Prochilodus lineatus [22] and Megaleporinus obtusidens [34], and the results of the connectivity have been corroborated with the maintenance of P. lineatus gene flow in the whole Upper Paraná Basin [113]. In this sense, it is fundamental that hydropower plants meet the necessary requirements [108], and should seek the installation of fishways, especially fish ladders, which allow for the voluntary and bidirectional passage of fish species [22].

This study conducted a data survey, a revision, and an update to technical scientific information of existing fishways in the Upper Paraná River Basin within Brazilian borders. Thus, hydropower plants, both current and future, in attending to the requirements of implementation, must enable the connectivity of critical habitats to migratory species via fish ladders. The designs of these fish ladders must meet the biological demands related to the behaviors and swimming capabilities of Neotropical migratory fish species. Although fish ladders are not a panacea to solve the environmental distresses caused by impoundments, they can mitigate impacts [22]. A feasible implementation with adequate designs of fish ladders in hydropower dams of the Upper Paraná River Basin is one of the fundamental requisites for the viability of maintaining connectivity, and therefore, the conservation of Neotropical long-distance migratory species.

Author Contributions: Conceptualization, S.M., M.C.M., L.F.C., A.P.S.B., J.F.M.S. and F.J.S.-R.; methodology, S.M., M.C.M., L.F.C., A.P.S.B., and J.F.M.S.; software, L.F.C. and J.F.M.; validation, S.M., M.C.M., L.F.C., A.P.S.B., J.F.M.S. and F.J.S.-R.; formal analysis, L.F.C. and J.F.M.; investigation, S.M., M.C.M., L.F.C., A.P.S.B., J.F.M.S.; data curation, L.F.C., J.F.M. and A.P.S.B.; writing-original draft preparation, S.M., M.C.M., L.F.C. and A.P.S.B.; writing-review and editing, S.M., M.C.M., L.F.C., J.F.M.S. and F.J.S.-R.; supervision, S.M., M.C.M.

Funding: This research received no external funding.

Acknowledgments: We are grateful to CNPq for the Productivity Grant in Technological Development and Innovative Extension-DT (SM), and Coordination for the Improvement of Higher Level Personnel-CAPES for the Doctoral scholarship (LFC) and Master scholarship (APSB). We are also grateful to the Araucária Foundation for technical fellowship (JFMS). Any use of trade, firm, or product names is for descriptive purposes only and does not imply endorsement.

Conflicts of Interest: The authors declare no conflict of interest. 


\section{Appendix A}

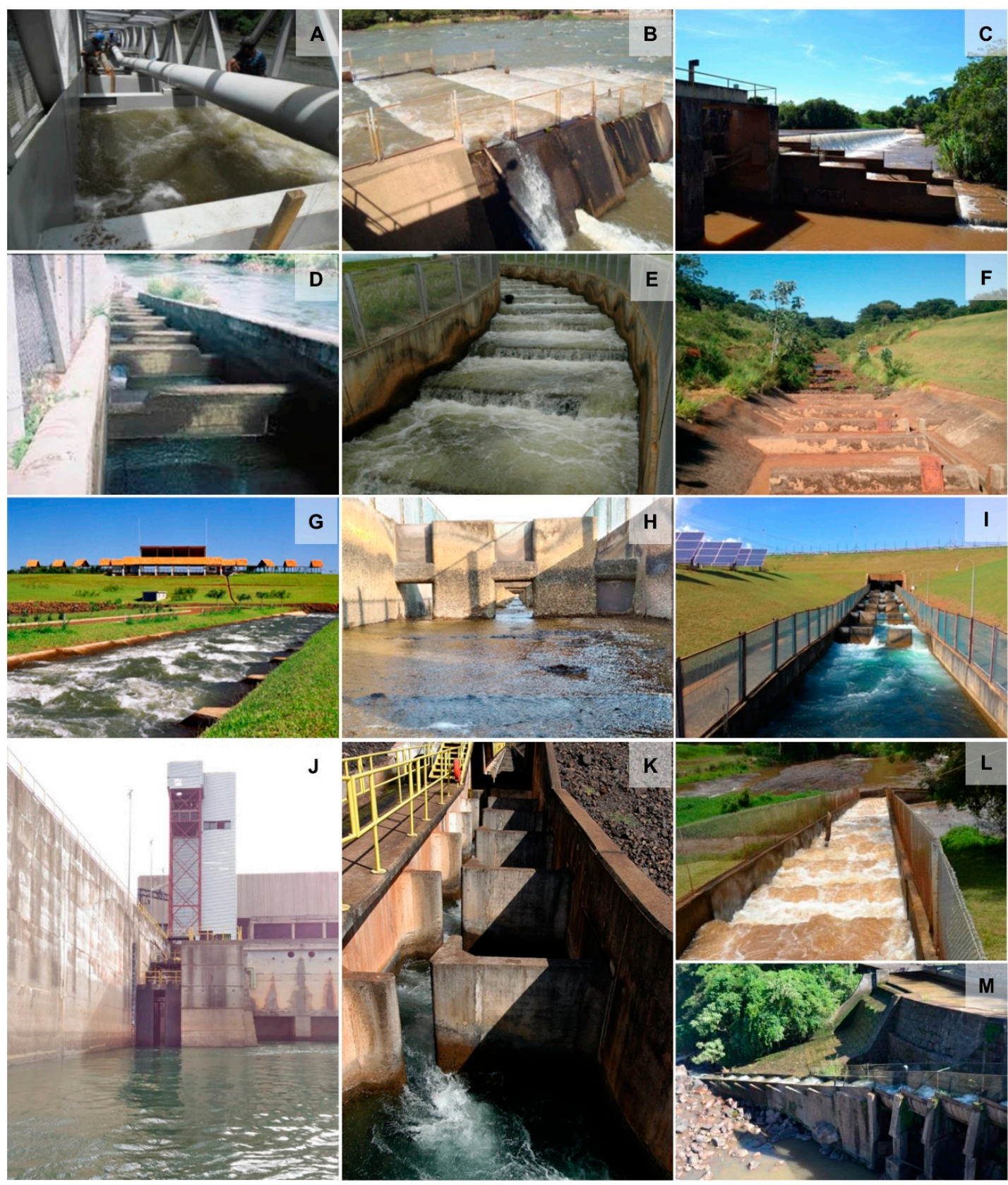

Figure A1. Weir and orifice fish ladder constructed in metal at the UHE São Domingos-Photo: [61] (A). Pool and weir fish ladder constructed in the Cachoeira das Emas PCH—Photo: [82] (B). Pool and weir fish ladder constructed at the São Joaquim PCH—Photo: [102] (C). Weir and orifice fish ladder of the Canoas I UHE, without water-Photo: [58] (D). Weir and orifice ladder of the Canoas II UHE with water-Photo: [103] (E). lateral system (Canal da Piracema) of ITAIPU without water-Photo: Leandro F. Celestino (F). Example of a mixed system (Canal da Piracema) of ITAIPU with water-Photo: [104] (G). Weir and orifice fish ladder of the Engenheiro Sérgio Motta UHE without water-Photo: Leandro F. Celestino (H). Weir and orifice fish ladder of the Engenheiro Sérgio Motta with water-Photo: Leandro F. Celestino (I). Elevator of Engenheiro Sérgio Motta UHE-Photo: Leandro F. Celestino (J). Example of a vertical slot at Igarapava UHE-Photo: [105] (K). Pool and weir as part of a mixed ladder at Galvão-Peixoto PCH-Photo: [106] (L), Pool and weir fish ladder constructed at Salto Grande PCH-Photo: [107] (M). 


\section{References}

1. Zarfl, C.; Lumsdon, A.E.; Berlekamp, J.; Tydecks, L.; Tockner, K. A global boom in hydropower dam construction. Aquat. Sci. 2015, 77, 161-170. [CrossRef]

2. Albins, M.; Evans, A.; Ismail, G.; Neilsen, B.; Pusack, T.; Schemmel, E.; Smith, W.; Stoike, S.; Li, H.W.; Noakes, D.L.G. Can humans coexist with fishes? Environ. Biol. Fishes 2013, 96, 1301-1313. [CrossRef]

3. Timpe, K.; Kaplan, D. The changing hydrology of a dammed Amazon. Sci. Adv. 2017, 3, 1-14. [CrossRef] [PubMed]

4. Agostinho, A.; Pelicice, F.; Gomes, L. Dams and the fish fauna of the Neotropical region: Impacts and management related to diversity and fisheries. Brazi. J. Biol. 2008, 68, 1119-1132. [CrossRef]

5. Ward, J.V.; Stanford, J.A. Ecological connectivity in alluvial river ecosystems and its disruption by flow regulation. Regul. Rivers Res. Manag. 1995, 11, 105-119. [CrossRef]

6. Barletta, M.; Jaureguizar, A.J.; Baigun, C.; Fontoura, N.F.; Agostinho, A.A.; Almeida-Val, V.M.F.; Val, A.L.; Torres, R.A.; Jimenes-Segura, L.F.; Giarrizzo, T.; et al. Fish and aquatic habitat conservation in South America: A continental overview with emphasis on neotropical systems. J. Fish Biol. 2010, 76, 2118-2176. [CrossRef]

7. Gouskov, A.; Reyes, M.; Wirthner-Bitterlin, L.; Vorburger, C. Fish population genetic structure shaped by hydroelectric power plants in the upper Rhine catchment. Evol. Appl. 2016, 9, 394-408. [CrossRef]

8. Lucas, M.C.; Baras, E. Migration of Freshwater Fishes; Wiley Online Library: Oxford, UK, 2001.

9. Moraes, P.; Deverat, F. An Introduction to Fish Migration; Moraes, P., Deverat, F., Eds.; Taylor \& Francis Group: London, UK, 2016; ISBN 978-1-4987-1874-5.

10. Langeani, F.; Oyakawa, O.T.; Shibatta, A.O.; Pavanelli, C.S.; Casatti, L. Diversidade da ictiofauna do Alto Rio Paraná: Composição atual e perspectivas futuras. Biota Neotrop. 2007, 7, 1-18. [CrossRef]

11. Agostinho, A.A.; Gomes, L.C.; Suzuki, H.I.; Júlio-Júnior, H.F. Migratory fishes of the Upper Paraná River Basin, Brazil. In Migratory Fishes of South America; Carolsfeld, J., Harvey, B., Ross, C., Baer, A., Eds.; World Bank: Washington, DC, USA, 2003; ISBN 0-9683958-2-12.

12. Suzuki, H.I.; de Vazzoler, A.E.A.M.; Marques, E.E.; Lizama, M.L.A.P.; Inada, P. Reproductive Ecology of the Fish Assemblages. In Upper Paraná River and its Floodplain: Physical Aspects, Ecology and Conservation; Thomaz, S.M., Agostinho, A.A., Hahn, N.S., Eds.; Backhuys Publishers: Leiden, The Netherlands, 2004; pp. 271-292.

13. Makrakis, M.C.; Miranda, L.E.; Makrakis, S.; Fontes, H.M.; Morlis, W.G.; Dias, J.H.P.; Garcia, J.O. Diversity in migratory patterns among Neotropical fishes. J. Fish Biol. 2012, 81, 866-881. [CrossRef]

14. Godinho, A.L.; Kynard, B. Migratory fishes of Brazil: Life history and fish passage needs. River Res. Appl. 2008, 25, 702-712. [CrossRef]

15. Godoy, M.P. Peixes do Brasil, Subordem Characoidei: Bacia do Rio Mogí Guassú; Franciscana: Piracicaba, Brazil, 1975.

16. Cowx, I.G.; Welcomme, R.L. Rehabilitation of Rivers for Fish; Food \& Agriculture Organization: Rome, Italy, 1998.

17. Da Silva, P.S.; Makrakis, M.C.; Miranda, L.E.; Makrakis, S.; Assumpção, L.; Paula, S.; Dias, J.H.P.; Marques, H. Importance of reservoir tributaries to spawning of migratory fish in the upper Paraná River. River Res. Appl. 2015, 31, 313-322. [CrossRef]

18. Quirós, R. The Paraná river basin development and the changes in the lower basin fisheries. Interciencia 1990, 15, 442-451.

19. Hoeinghaus, D.J.; Agostinho, A.A.; Gomes, L.C.; Pelicice, F.M.; Okada, E.K.; Latini, J.D.; Kashiwaqui, E.A.L.; Winemiller, K.O. Effects of river impoundment on ecosystem services of large tropical rivers: Embodied energy and market value of artisanal fisheries. Conserv. Biol. 2009, 23, 1222-1231. [CrossRef] [PubMed]

20. Porcher, J.P.; Travade, F. Fishways: Biological basis, limits and legal considerations. Bull. Français la Pêche la Piscic. 2002, 364, 9-20. [CrossRef]

21. Clay, C.H. Design of Fishways and Other Fish Facilities, 2nd ed.; CRC Press: Boca Raton, FL, USA, 1995.

22. Celestino, L.F.; Sanz-Ronda, F.J.; Miranda, L.E.; Makrakis, M.C.; Dias, J.H.P.; Makrakis, S. Bidirectional connectivity via fish ladders in a large Neotropical river. River Res. Appl. 2019, 35, 236-246. [CrossRef]

23. Larinier, M. Fishways-General consideration. Bull. Français La Pêche La Piscic. 2002, 364, 21-27. [CrossRef]

24. DVWK. Fish Passages—Design, Dimension and Monitoring; FAO_Food and Agriculture Organization of the United Nations: Rome, Italy, 2002; ISBN 92-5-104894-0. 
25. Castro-Santos, T.; Cotel, A.; Webb, P. Fishway evaluations for better bioengineering: An Integrative approach a framework for fishway. Am. Fish. Soc. 2009, 69, 557-575.

26. Silva, A.T.; Lucas, M.C.; Castro-Santos, T.; Katopodis, C.; Baumgartner, L.J.; Thiem, J.D.; Aarestrup, K.; Pompeu, P.S.; O'Brien, G.C.; Braun, D.C.; et al. The future of fish passage science, engineering, and practice. Fish Fish. 2018, 19, 340-362. [CrossRef]

27. Larinier, M. Environmental Issues, Dams and Fish Migration. In Dams, Fish and Fisheries: Opportunities, Challenges and Conflict Resolution; Marmulla, G., Ed.; Fisheries Techinical Paper; FAO Food and Agriculture Organization: Rome, Italy, 2001; pp. 45-90, ISBN 92-5-104694-8.

28. Gustafsson, S.; Österling, M.; Skurdal, J.; Schneider, L.D.; Calles, O. Macroinvertebrate colonization of a nature-like fishway: The effects of adding habitat heterogeneity. Ecol. Eng. 2013, 61, 345-353. [CrossRef]

29. Dodd, J.R.; Cowx, I.G.; Bolland, J.D. Efficiency of a nature-like bypass channel for restoring longitudinal connectivity for a river-resident population of brown trout. J. Environ. Manag. 2017, 204, 318-326. [CrossRef]

30. Calles, O.; Greenberg, L. Connectivity is a two-way street-the need for a holistic approach to fish passage problems in regulated rivers. River Res. Appl. 2009, 25, 1268-1286. [CrossRef]

31. Pander, J.; Mueller, M.; Geist, J. Ecological functions of fish bypass channels in streams: Migration corridor and habitat for rheophilic spceies. River Res. Appl. 2013, 29, 441-450. [CrossRef]

32. Rajaratnam, N.; Van der Vinne, G.; Katopodis, C. Hydraulics of Vertical Slot Fishways. J. Hydraul. Eng. 1986, 112, 909-927. [CrossRef]

33. Katopodis, C.; Williams, J.G. The development of fish passage research in a historical context. Ecol. Eng. 2012, 48, 8-18. [CrossRef]

34. Gutfreund, C.; Makrakis, S.; Castro-Santos, T.; Celestino, L.F.; Dias, J.H.P.; Makrakis, M.C. Effectiveness of a fish ladder for two Neotropical migratory species in the Paraná River. Mar. Freshw. Res. 2018, 1-9. [CrossRef]

35. Quirós, R. Structures Assisting the Migrations of Non-Salmonid Fish: Latin America; Quirós, R., Ed.; Techinical Paper. N5; COPESCAL: Rome, Italy, 1989; ISBN 92-5-102683-1.

36. Fernandez, D.R.; Agostinho, A.A.; Bini, L.M.; Pelicice, F.M. Diel variation in the ascent of fishes up an experimental fish ladder at Itaipu Reservoir: Fish size, reproductive stage and taxonomic group influences. Neotrop. Ichthyol. 2007, 5, 215-222. [CrossRef]

37. De Santos, H.A.; Viana, E.M.F.; Pompeu, P.S.; Martinez, C.B. Optimal swim speeds by respirometer: An analysis of three neotropical species. Neotrop. Ichthyol. 2012, 10, 805-811. [CrossRef]

38. Assumpção, L.; Makrakis, M.C.; Makrakis, S.; Wagner, R.L.; Da Silva, P.S.; De Lima, A.F.; Kashiwaqui, E.A.L. The use of morphometric analysis to predict the swimming efficiency of two Neotropical long-distance migratory species in fish passage. Neotrop. Ichthyol. 2012, 10, 797-804. [CrossRef]

39. Bido, A.F.; Urbinati, E.C.; Makrakis, M.C.; Celestino, L.F.; Serra, M.; Makrakis, S. Stress indicators for Prochilodus lineatus (Characiformes: Prochilodontidae) breeders during passage through a fish ladder. Mar. Freshw. Res. 2018, 1-8. [CrossRef]

40. Castro-Santos, T.; Haro, A. Fish Guidance and Passage at Barriers. In Fish Locomotion: An Eco-Ethological Perspective; Domenici, P., Kapoor, B.G., Eds.; Science Publisher: Enfield, NH, USA, 2010; pp. 62-89.

41. Fontes, H.M., Jr.; Castro-santos, T.; Makrakis, S.; Gomes, L.C.; Latini, J.D. A barrier to upstream migration in the fish passage of Itaipu Dam (Canal da Piracema), Paraná River basin. Neotrop. Ichthyol. 2012, 10, 697-704. [CrossRef]

42. Oldani, N.O.; Baigún, C.R.M. Performance of a fishway system in a major South American dam on the Parana River (Argentina-Paraguay). River Res. Appl. 2002, 18, 171-183. [CrossRef]

43. Almeida, L.E.G.; Mattos, M.E.; Tanaka, H.R. Modernização da PCH Gavião Peixoto: Gestão, controle ambiental e mecanismo de desenvolvimento limpo. Semin. Nac. PRODUÇÃO E Transm. Energ. ELÉTRICA 2010, 7.

44. Lira, N.A.; Pompeu, P.S.; Agostinho, C.S.; Agostinho, A.A.; Arcifa, M.S.; Pelicice, F.M. Fish passages in South America: An overview of studied facilities and research effort. Neotrop. Ichthyol. 2017, 15, 1-14. [CrossRef]

45. Cooke, S.J.; Hinch, S.G. Improving the reliability of fishway attraction and passage efficiency estimates to inform fishway engineering, science, and practice. Ecol. Eng. 2013, 58, 123-132. [CrossRef]

46. Castro-Santos, T.; Haro, A.; Walk, S. A passive integrated transponder (PIT) tag system for monitoring fishways. Fish. Res. 1996, 28, 253-261. [CrossRef] 
47. Energy, D. ABC da Energia. 2013. Available online: https://abc-da-energia.webnode.com/ (accessed on 5 July 2019).

48. Britto, S.G.D.C.; Carvalho, E.D. Reproductive migration of fish and movement in a series of reservoirs in the Upper Parana River basin, Brazil. Fish. Manag. Ecol. 2013, 20, 426-433. [CrossRef]

49. Auffret, A.G.; Plue, J.; Cousins, S.A.O. The spatial and temporal components of functional connectivity in fragmented landscapes. Ambio 2015, 44, 51-59. [CrossRef] [PubMed]

50. Orfeo, O.; Stevaux, J. Hydraulic and morphological characteristics of middle and upper reaches of the Paraná River (Argentina and Brazil). Geomorphology 2002, 44, 309-322. [CrossRef]

51. QGIS Development Team. Development Geographic Information System User Guide. Open Source Geospatial Foundation Project 2019; QGIS Development Team: Grut, Switzerland, 2019.

52. ANEEL-Agência Nacional de Energia Elétrica. Resolução Normativa $N^{\circ}$ 687, de 24 de Novembro de 2015; Gência Nacional de Energia Elétrica: Brasilia, Brazil, 2015.

53. ANEEL-Agência Nacional de Energia Elétrica Resolução Normativa $N^{\circ}$ 673, de 4 de Agosto de 2015; Gência Nacional de Energia Elétrica: Brasilia, Brazil, 2015.

54. ANEEL. Atlas de Energia Elétrica do Brasil, 3rd ed.; de Elétrica, A.N.E., Ed.; Agência Nacional de Energia Elétrica: Brasilia, Brazil, 2008; ISBN 978-85-87491-10-7.

55. São Paulo. Decreto $N^{\circ}$ 63.853, de 27 de Novembro de 2018. São Paulo. 2018. Available online: https://www. al.sp.gov.br/repositorio/legislacao/decreto/2018/decreto-63853-27.11.2018.html (accessed on 5 July 2019).

56. Brasil Portaria do Ministério do Meio Ambiente (MMA). 445, de 17 de Dezembro de 2014. Reconhece Como Espécies de Peixes e Invertebrados Aquáticos da Fauna Brasileira Ameaçadas de Extinção Aquelas Constantes da Lista Nacional Oficial de Espécies da Fauna Ameaçada; Brasil Portaria do Ministério do Meio Ambiente: Brasilia, Brazil, 2014; pp. 126-130.

57. Da Ingenito, L.F.S.; Duboc, L.F.; Abilhoa, V. Contribuição ao conhecimento da ictiofauna da bacia do alto rio Iguaçu, Paraná, Brasil. Arq. Ciências Veterinárias e Zool. da Unipar 2004, 7, $23-36$.

58. De Vazzoler, A.E.A.M. Biologia da Reprodução de Peixes Teleósteos: Teoria e Prática; Eduem: Maringá, Brazil, 1996; ISBN 85-85545-16-X.

59. Ota, R.R.; de Deprá, G.C.; da Graça, W.J.; Pavanelli, C.S. Peixes da planície de inundação do alto rio Paraná e áreas adjacentes: Revised, annotated and updated. Neotrop. Ichthyol. 2018, 16, 1-111. [CrossRef]

60. Hahn, N.S.; Fugi, R.; Andrian, I.F. Trophic Ecology of Fish Assemblages. In The Upper Paraná River Floodplain: Physical Aspects, Ecology and Conservation; Thomaz, S.M., Agostinho, A.A., Hahn, N.S., Eds.; Backhuys Publishers: Leiden, The Netherlands, 2004; pp. 247-269.

61. De Resende, E.K. Migratory Fishes of the Paraguay-Paraná Basin. In Migratoty Fishes of South America: Biology, Fisheries, and Conservation Status; Carolsfeld, J., Harvey, B., Ross, C., Baer, A., Eds.; World Fisheries Trust: Washington, DC, USA, 2003; pp. 98-155.

62. Agostinho, A.A.; Gomes, L.C.; Pelicice, F.M. Ecologia e Manejo de Recursos Pesqueiros em Rereservatórios do Brasil; EDUEM: Maringá, Brazil, 2007.

63. Godinho, A.L.; Lamas, I.R.; Godinho, H.P. Reproductive ecology of Brazilian freshwater fishes. Environ. Biol. Fishes 2010, 87, 143-162. [CrossRef]

64. Bowen, M.D.; Marques, S.; Silva, L.G.M.; Vono, V.; Godinho, H.P. Comparing on site human and video counts at Igarapava fish ladder, Southeastern Brazil. Neotrop. Ichthyol. 2006, 4, 291-294. [CrossRef]

65. Bizzotto, P.M.; Godinho, A.L.; Vono, V.; Kynard, B.; Godinho, H.P. Influence of seasonal, diel, lunar, and other environmental factors on upstream fish passage in the Igarapava Fish Ladder, Brazil. Ecol. Freshw. Fish 2009, 18, 461-472. [CrossRef]

66. Lopes, C.M.; De Almeida, F.S.; Orsi, M.L.; Britto, S.G.D.C.; Sirol, R.N.; Sodré, L.M.K. Fish passage ladders from Canoas Complex-Paranapanema River: Evaluation of genetic structure maintenance of Salminus brasiliensis (Teleostei: Characiformes). Neotrop. Ichthyol. 2007, 5, 131-138. [CrossRef]

67. Britto, S.G.D.C. A estratégia reprodutiva dos peixes migradores frente às escacda do complexo canoas (rio Paranapanema, bacia do alto Paraná). Ph.D. Thesis, Universidade Estadual Paulista, Sao Paolo, Brazil, 2009.

68. Arcifa, M.S.; Luiz, A.; Esguícero, H. The fish fauna in the fish passage at the Ourinhos Dam, Paranapanema River. Neotrop. Ichthyol. 2012, 10, 715-722. [CrossRef]

69. Martins, S.L. Sistemas Para a Transposição de Peixes Neotropicais Potamódromos. Ph.D. Thesis, Universidade Estadual Paulista, Sao Paolo, Brazil, 2005. 
70. De Viana, E.M.F. Mapeamento do Campo de Velocidades em Mecanismos de Transposição de Peixes do Tipo Slot Vertical em Diferentes Escale. Ph.D. Thesis, Universidade Federal de Minas Gerais, Belo Horizonte, Brazil, 2005.

71. Godoy, M.P. Aqüicultira-Atividade Multidisciplinar e Outras Facilidades Para Passagens de Peixes, Estações de Piscicultura; Eletrosul: Florianópolis, Brazil, 1985.

72. Eletrosul. $5^{\circ}$ Relatório Semestral de Andamento dos Programas e Planos Ambietais; Fase de Operação UHE São Domingos; Eletrosul: Florianópolis, Brazil, 2015; Volume 1.

73. Makrakis, S.; Makrakis, M.C.; Wagner, R.L.; Dias, J.H.P.; Gomes, L.C. Utilization of the fish ladder at the Engenheiro Sergio Motta Dam, Brazil, by long distance migrating potamodromous species. Neotrop. Ichthyol. 2007, 5, 197-204. [CrossRef]

74. Wagner, R.L.; Makrakis, S.; Castro-Santos, T.; Makrakis, M.C.; Dias, J.H.P.; Belmont, R.F. Passage performance of long-distance upstream migrants at a large dam on the Paraná River and the compounding effects of entry and ascent. Neotrop. Ichthyol. 2012, 10, 785-795. [CrossRef]

75. Volpato, G.L.; Barreto, R.E.; Marcondes, A.L.; Andrade Moreira, P.S.; de Barros Ferreira, M.F. Fish ladders select fish traits on migration-still a growing problem for natural fish populations. Mar. Freshw. Behav. Physiol. 2009, 42, 307-313. [CrossRef]

76. CESP. Programa de Manejo Pesqueiro: Plano de Trabalho 2000-2001; CESP: São Paulo, Brazil, 2000.

77. CESP. Programa de Manejo Pesqueiro: Plano de Trabalho 2002-2003; CESP: São Paulo, Brazil, 2002.

78. CESP. Programa de Manejo Pesqueiro: Plano de Trabalho 2003-2004; CESP: São Paulo, Brazil, 2003.

79. Makrakis, S.; Makrakis, M.C.; Da Silva, P.S.; Celestino, L.F. Monitoramento do Ictioplâncton em Tributários do Reservatório de Porto Primavera e Monitoramento da Transposição; Unioeste: Toledo, Brazil, 2015.

80. Makrakis, S.; Gomes, L.C.; Makrakis, M.C.; Fernandez, D.R.; Pavanelli, C.S. The Canal da Piracema at Itaipu Dam as a fish pass system. Neotrop. Ichthyol. 2007, 5, 185-195. [CrossRef]

81. Hahn, L.; English, K.; Carosfeld, J.; Gustavo, L.; Latini, J.D.; Agostinho, A.A.; Fernandez, D.R. Preliminary study on the application of radio-telemetry techniques to evaluate movements of fish in the Lateral canal at Itaipu Dam, Brazil. Neotrop. Ichthyol. 2007, 5, 103-108. [CrossRef]

82. Makrakis, S.; Miranda, L.E.; Gomes, L.C.; Makrakis, M.C.; Junior, H.M.F.J. Ascent of neotropical fish in the Itaipu reservoir fish pass. River Res. Appl. 2011, 27, 511-519. [CrossRef]

83. Google Maps. Available online: https://www.google.com.br/maps (accessed on 15 February 2018).

84. Suzuki, F.M.; Pires, L.V.; Pompeu, P.S. Passage of fish larvae and eggs through the Funil, Itutinga and Camargos Reservoirs on the upper Rio Grande (Minas Gerais, Brazil). Neotrop. Ichthyol. 2011, 9, 617-622. [CrossRef]

85. Aliança Usina de Funil. Available online: https://aliancaenergia.com.br/br/nossas-usinas/usina-de-funil (accessed on 24 April 2019).

86. Shibatta, O.A.; Gealh, A.M.; Bennemann, S.T. Ictiofauna dos trechos alto e médio da bacia do rio Tibagi, Paraná, Brasil. Biota Neotrop. 2007, 7, 125-134. [CrossRef]

87. Godinho, H.P.; Godinho, A.L.; Formagio, P.S.; Torquato, V.C. Fish ladder efficiency in a southeastern Brazilian river. Cienc. Cult. 1991, 43, 63-67.

88. EMAE-Fundação de Energia e Saneamento. PCH Corubataí, Rio claro—SP.; Fundação de Energia e Saneamento: Sao Paulo, Brazil, 2014.

89. Ricardi, A.; Meneguello, C.; Bueno, E.; Santos, G.; Magalhães, G.; Limnos, G.; Bizello, M.L.; Xavier, M.; Diniz, R.; Furlan, S.; et al. Relaório Técnico da $8^{\circ}$ Expedição: Usinas Lobo, São Joaquim, Buritis; Esmeril: São Paulo, Brazil, 2015; Volume 8.

90. Mortati, D.; Bueno, E.; Dizzio, F.; Limnios, G.; Magalhães, G.; Midori, M.; Lima, N.; Gazoni, P.; Diniz, R.; Carvalho, T. Relatório Técnico da $2^{\circ}$ Expedição: Usinas de Porto Goes, Lavras, Salto Grande, Cariobinha, Carioba, America, Jaguari; Esmeril: São Paulo, Brazil, 2014; Volume 2.

91. Capeleti, A.R.; Petrere Jr, M. Migration of the curimbatá Prochilodus lineatus (Valenciennes, 1836) (Pisces, Prochilodontidae) at the waterfall "Cachoeira de Emas" of the Mogi-Guaçu river-São Paulo, Brazil. Brazilian J. Biol. 2006, 66, 651-659. [CrossRef]

92. Peressin, A.; Gonçalves, S.; Manoel, F.; Braga, D.S. Reproductive strategies of two Curimatidae species in a Mogi Guaçu impoundment, upper Paraná River basin, São Paulo, Brazil. Neotrop. Ichthyol. 2012, 10, 847-854. [CrossRef] 
93. Migliorini, P.C.P. Repotenciação da Pequena Central Hidrelétrica de Emas "Nova"—Pirassununga—SP: Aspectos Técnicos, Socioambientais e Economicos; Universidade de São Paulo: Sao Paulo, Brazil, 2011.

94. Gonçalves, C.D.S.; Braga, F.M.D.S. Diversidade e ocorrência de peixes na área de influência da UHE Mogi Guaçu e lagoas marginais, bacia do alto rio Paraná, São Paulo, Brasil. Biota Neotrop. 2008, 8, 103-114. [CrossRef]

95. Esguícero, A.L.H.; Arcifa, M.S. Fragmentation of a Neotropical migratory fish population by a century-old dam. Hydrobiologia 2010, 638, 41-53. [CrossRef]

96. Ricardi, A.; Argollo, A.; Freitas, C.; Barbanti, C.; Mortati, D.; Geribello, D.; Bueno, E.; Drizzo, F.; Santos, G.; Magalhães, G.; et al. Relatório técnico $5^{\circ}$ Expedição: Usinas de Corumbataí, Capão Pretro, Monjolinho, Lia-Marmelos I, II, III e Isabl. 2014. Available online: http://eletromemoria.fflch.usp.br/sites/eletromemoria. fflch.usp.br/files/relatorio_da_5a_expedicao.pdf (accessed on 5 July 2019).

97. Winemiller, K.O.; McIntyre, P.B.; Castello, L.; Fluet-Chouinard, E.; Giarrizzo, T.; Nam, S.; Baird, I.G.; Darwall, W.; Lujan, N.K.; Harrison, I.; et al. Balancing hydropower and biodiversity in the Amazon, Congo, and Mekong. Science 2016, 351, 128-129. [CrossRef] [PubMed]

98. Latrubesse, E.M.; Arima, E.Y.; Dunne, T.; Park, E.; Baker, V.R.; D’Horta, F.M.; Wight, C.; Wittmann, F.; Zuanon, J.; Baker, P.A.; et al. Damming the rivers of the Amazon basin. Nature 2017, 546, 363-369. [CrossRef]

99. ALESP. LEI N 9.798, de 07 de Outubro de 1997; Assembleia Legislativa do Estado de São Paulo: Sao Paulo, Brazil, 1997.

100. Minas Gerais. Lei $N^{\circ} 12.488$, de 9 de Abril de 1997. 1997. Available online: http://www.ctpeixes.ufmg.br/ html/conteudo/lei_12488.htm (accessed on 5 July 2019).

101. Agostinho, A.A.; Marques, E.E.; Agostinho, C.S.; Almeida, D.A.; Oliveira, R.J.; Rodrigues, J.; Melo, B. Fish ladder of Lajeado Dam: Migrations on one-way routes? Neotrop. Ichthyol. 2007, 5, 121-130. [CrossRef]

102. Agostinho, C.S.; Pelicice, F.M.; Marques, E.E.; Soares, A.B.; de Almeida, D.A.A. All that goes up must come down? Absence of downstream passage through a fish ladder in a large Amazonian river. Hydrobiologia 2011, 675, 1-12. [CrossRef]

103. Pelicice, F.M.; Agostinho, C.S. Deficient downstream passage through fish ladders: The case of Peixe Angical Dam, Tocantins River, Brazil. Neotrop. Ichthyol. 2012, 10, 705-713. [CrossRef]

104. Baigún, C.R.M.; Nestler, J.M.; Minotti, P.; Oldani, N.O. Fish passage system in an irrigation dam (Pilcomayo River basin): When engineering designs do not match ecohydraulic criteria. Neotrop. Ichthyol. 2012, 10, 741-750.

105. Oldani, N.O.; Baigún, C.R.M.; Nestler, J.M.; Goodwin, R.A. Is fish passage technology saving fish resources in the lower La Plata River basin? Neotrop. Ichthyol. 2007, 5, 89-102. [CrossRef]

106. Croze, O.; Bau, F.; Delmouly, L. Efficiency of a fish lift for returning Atlantic salmon at a large-scale hydroelectric complex in France. Fish. Manag. Ecol. 2008, 15, 467-476. [CrossRef]

107. Larinier, M.; Marmulla, G. Fish passes: Types, principles and geographical distribution-An overview. In Proceedings of the Second International Symposium on the Management of Large Rivers for Fisheries; Welcomme, R.L., Petr, T., Eds.; FAO Fisheries: Bangkok, Thailand, 2004; pp. 183-206, ISBN 974-7946-65-3.

108. Makrakis, S.; Dias, J.H.P.; Lopes, J.D.M.; Fontes-Junior, H.M.; Godinho, A.L.; Martinez, C.B.; Makrakis, M.C. Premissas e Critérios Mínimos para Implantação, Avaliação e Monitoramento de Sistemas de Transposição para Peixes. Bol. Soc. Bras. Ictiol. 2015, 114.

109. Pelicice, F.M.; Azevedo-Santos, V.M.; Esguícero, A.L.H.; Agostinho, A.A.; Arcifa, M.S. Fish diversity in the cascade of reservoirs along the Paranapanema River, southeast Brazil. Neotrop. Ichthyol. 2018, 16, 1-18. [CrossRef]

110. Da Silva, P.S.; Miranda, L.E.; Makrakis, S.; Assumpção, L.; Dias, J.H.P.; Makrakis, M.C. Tributaries as biodiversity preserves: An ichthyoplankton perspective from the severely impounded Upper Paraná River. Aquat. Conserv. Mar. Freshw. Ecosyst. 2019, 258-269. [CrossRef]

111. Marques, H.; Dias, J.H.P.; Perbiche-Neves, G.; Kashiwaqui, E.A.L.; Ramos, I.P. Importance of dam-free tributaries for conserving fish biodiversity in Neotropical reservoirs. Biol. Conserv. 2018, 224, 347-354. [CrossRef] 
112. Assumpção, L.; Makrakis, S.; Sarai, P.; Makrakis, M.C. Espécies de peixes ameaçadas de extinção no Parque Nacional do Iguaçu. Biodiversidade Bras. 2017, 7, 4-17.

113. Ferreira, D.G.; Souza-Shibatta, L.; Shibatta, O.A.; Sofia, S.H.; Carlsson, J.; Dias, J.H.P.; Makrakis, S.; Makrakis, M.C. Genetic structure and diversity of migratory freshwater fish in a fragmented Neotropical river system. Rev. Fish Biol. Fish. 2017, 27, 209-231. [CrossRef]

(C) 2019 by the authors. Licensee MDPI, Basel, Switzerland. This article is an open access article distributed under the terms and conditions of the Creative Commons Attribution (CC BY) license (http://creativecommons.org/licenses/by/4.0/). 